Archive for

Organic Chemistry

Arkivoc 2018, part vi, 0-0

\title{
Newly discovered naturally occurring organohalogens
}

\author{
Gordon W. Gribble \\ Department of Chemistry, Dartmouth College, Hanover, NH 03755, USA \\ E-mail:ggribble@dartmouth.edu
}

Dedicated to the memories of these pioneers in the field of marine natural products:

Paul J. Scheuer, Richard E. Moore, and D. John Faulkner

Received 05-02-2018

Accepted 08-26-2018

Published on line 11-03-2018

\section{Abstract}

Last year more than 200 naturally occurring organohalogens were described for the first time. These natural products were isolated and characterized from marine algae, sponges, corals, tunicates, bryozoans, marine and terrestrial fungi and bacteria, cyanobacteria, terrestrial plants, slime molds, red ants, and interstellar space. The following examples are illustrative of the extraordinary synthetic virtuosity of nature.<smiles>CC1(C)[C@@H](Br)CC/C(=C\I)[C@@H]1CC[C@]1(C)[C@@H](Br)CC/C(=C\I)[C@@H]1Cc1cc(Br)cc(I)c1O</smiles>

iodocallophycol B

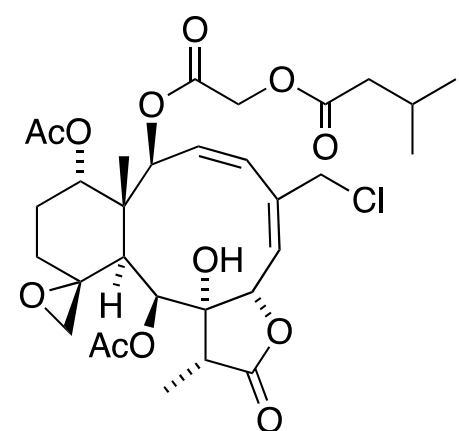

fragilolide $\mathrm{O}$<smiles>COc1ccc2c(c1OC)O[C@@]1(C2=O)N(C)C(=O)[C@]2(SC)C[C@]3(O)[C@@H](Cl)C=C[C@H](O)[C@H]3ON12</smiles>

penicisulfuranol D

Keywords: Organohalogen, organochlorine, organobromine, organoiodine, marine natural products, terrestrial natural products, bacteria, fungi, sponges, algae, corals, marine organisms 


\section{Table of Contents}

1. Introduction

2. Discussion

2.1 Marine plants

2.2 Sponges

2.3 Corals

2.4 Tunicates

2.5 Bryozoans

2.6 Marine fungi

2.7 Marine bacteria

2.8 Cyanobacteria

2.9 Other marine organisms

2.10 Terrestrial plants

2.11 Terrestrial fungi

2.12 Terrestrial bacteria

2.13 Slime mold

2.14 Miscellaneous

3. Conclusions

4. Acknowledgements

5. References

\section{Introduction}

From fewer than 50 known naturally occurring organohalogens in $1968,{ }^{1}$ the number today - fifty years later is more than 5,000. Three comprehensive reviews are available, ${ }^{2-4}$ as are more recent separate compilations of halogenated alkaloids, ${ }^{5}$ marine natural products, ${ }^{6}$ and halogenated heterocyclic compounds that occur naturally. ${ }^{7}$ A recent review of naturally occurring organoiodides has also appeared, ${ }^{8}$ and the annual review of marine natural products routinely covers new halogenated marine compounds for that year. ${ }^{9}$ It should be noted that previously known organohalogens and non-halogenated natural products discovered in the cited papers are not included in this review.

\section{Discussion}

\subsection{Marine plants}

The most prolific source of marine organohalogen natural products is the seaweed "limu kohu" (Asparagopsis taxiformis), a delicacy of native Hawaiians and which has yielded more 100 organohalogens. The major component of this red alga is bromoform $\left(\mathrm{CHBr}_{3}\right)$, along with several lachrymatory $\alpha$-haloketones. ${ }^{2}$ This author believes that the "smell of the ocean" is in large part due to the omnipresent organohalogens exuded by algae, $\mathrm{CHBr}_{3}, \mathrm{CH}_{2} \mathrm{Cl}_{2}, \mathrm{CHCl}_{3}, \mathrm{CH}_{3} \mathrm{Br}, \mathrm{CH}_{3} \mathrm{l}, \mathrm{CH}_{2} \mathrm{Br}, \mathrm{CH}_{2} \mathrm{Brl}, \mathrm{CH}_{2} \mathrm{I}_{2}, \mathrm{CHI}_{3}, \mathrm{CHCl}_{2} \mathrm{Br}, \mathrm{CHClBr}_{2}, \mathrm{CHBr}_{2} \mathrm{I}, \mathrm{CHBrl}_{2}$, $\mathrm{CHClBrl}, \mathrm{CH}_{3} \mathrm{CH}_{2} \mathrm{Br}, \mathrm{CH}_{3} \mathrm{CH}_{2} \mathrm{I}, \mathrm{CH}_{3} \mathrm{CH}_{2} \mathrm{CH}_{2} \mathrm{Br}, \mathrm{CH}_{3} \mathrm{CH}_{2} \mathrm{CH}_{2} \mathrm{I},\left(\mathrm{CH}_{3}\right)_{2} \mathrm{CHI}$, and others. ${ }^{2}$ 
The ubiquitous red algal genus Laurencia is a fertile source of organohalogens and last year saw the discovery of several new such metabolites. A collection of Laurencia obtusa from the Red Sea yielded the new maneonene, jeddahenyne A (1), and the novel isomaneonene, 12-debromo-12-methoxy isomaneonene A (2) along with several known compounds. ${ }^{10}$ An examination of Laurencia viridis from the Canary Islands has furnished four new acetogenins $3-6,{ }^{11}$ which are variants of the known pinnatifidenyne $C_{15}$ acetogenins (Figure 1). Oxirane 5 shows modest activity against four human solid tumor cell lines $\left(\mathrm{GI}_{50}=13-48 \mu \mathrm{M}\right)$, and 4 is active against two of the cell lines $\left(G I_{50}=33-45 \mu \mathrm{M}\right)$.

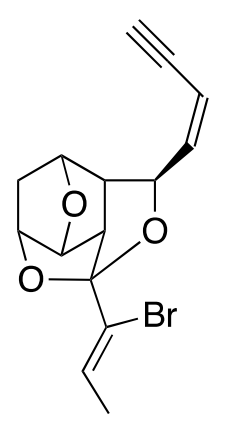

1 (jeddahenyne A)

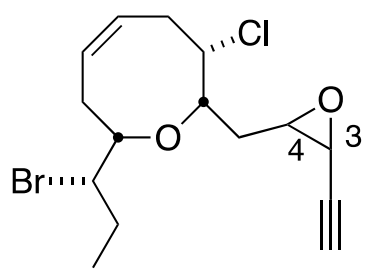

3 (3R,4S)-epoxy-pinnatifidenyne)

4 (3S,4R)-epoxy-pinnatifidenyne)

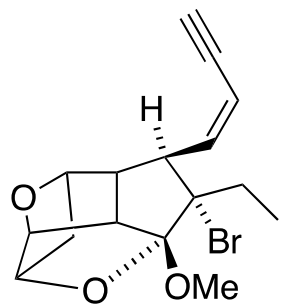

2 (12-debromo-12-methoxyisomaneonene)

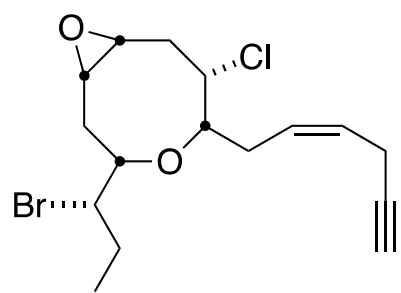

5 (9R,10S)-epoxy-Z-pinnatifidenyne)

Figure 1. Structures of new Laurencia sp. Organohalogens.

Eleven halogenated chamigrenes, compositacins (7 - 17), were isolated from the red alga Laurencia composita Yamada collected along the coast of Nanji Island in the East China Sea (Figure 2). ${ }^{12}$ Only compositacin $\mathrm{G}(\mathbf{1 3})$ shows good activity against the fungus Microsporum gypseum $\left(\mathrm{MIC}_{80}=4 \mu \mathrm{g} / \mathrm{mL}\right), \mathrm{while}$ compositacins $D$ and $G$ exhibit marginal cytotoxiciy towards the A-549 human lung adenocarcinoma cell line (49- $85 \mu \mathrm{M})$. The absolute configurations of compositacin B (8) was determined by the time-dependent density functional theory electronic circular dichroism (TDDFT-ECD) method, and those of compositacins $A$ (7) and C - K (9-17) were established on biosynthetic grounds by comparison to compositacin $B$ and to related sesquiterpenoids. 
<smiles>CC1=CC[C@@H](C)[C@](C)(O)[C@]12CC[C@@](C)(Cl)[C@@H](Br)C2</smiles>

7 (compositacin A)<smiles>CC1(C)C(Br)=C[C@@H]2O[C@H]2C12CC1CC[C@]2(C)O1</smiles>

10 (compositacin D)<smiles>CC1(C)CC23C=CC(OC2CC1Br)C(=O)C3(C)C</smiles>

8 (compositacin B)<smiles>[R7]C1(O)C=C(Br)C(C)(C)[C@@]2(C)C[C@H](Br)[C@@](C)(Cl)CC[C@]12C</smiles>

11, $R^{1}=H, R^{2}=O M e$ (compositacin $E$ ) 12, $R^{1}=\mathrm{OMe}, \mathrm{R}^{2}=\mathrm{H}$ (compositacin $\mathrm{F}$ )<smiles>CC1(C)CC[C@]2(CC1Br)C(C)(C)C(=O)C=C[C@]2(C)O</smiles>

9 (compositacin C)<smiles>CC1(Cl)CC[C@@]2(CC3O[C@]2(C)C(Br)C=C3Br)C(C)(C)C1</smiles>

13 (compositacin G)<smiles>[R9]CC1=C[C@H](O)C(Br)C(C)(C)[C@]12CC[C@@]([R7])(Br)[C@@H](Br)C2</smiles>

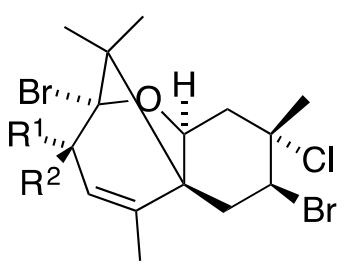

14, $\mathrm{R}^{1}=\mathrm{Cl}, \mathrm{R}^{2}=\mathrm{Me}, \mathrm{R}^{3}=\mathrm{H}$ (compositacin $\mathrm{H}$ )

15, $R^{1}=\mathrm{Me}, \mathrm{R}^{2}=\mathrm{Cl}, \mathrm{R}^{3}=\mathrm{OAc}$ (compositacin I)

16, $\mathrm{R}^{1}=\mathrm{OH}, \mathrm{R}^{2}=\mathrm{H}$ (compositacin $\mathrm{J}$ )

17, $R^{1}=R^{2}=O($ compositacin $K$ )

Figure 2. Structures of new Laurencia composita halogenated chamigrenes.

Four separate collections of Laurencia sp. (L. okamurae and L. nipponica) from Japanese coastal waters yielded the new omaezol (18), intricatriol (19), and hachijojimallenes A (20) and B (21) (Figure 3). ${ }^{13}$ Omaezol (18) and hachijojimallene $A(20)$ demonstrate potent antifouiling activity against larvae of the barnacle Amphibalanus amphitrite $\left(\mathrm{EC}_{50}=0.31-0.59 \mu \mathrm{M}\right)$, comparable to $\mathrm{CuSO}_{4}\left(\mathrm{EC}_{50}=0.71 \mu \mathrm{M}\right)$.

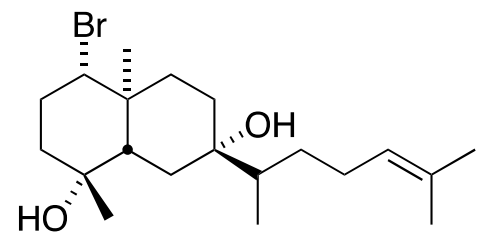

18 (omaezol)

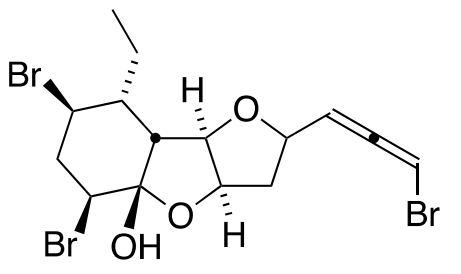

20 (hachijojimallene A)<smiles>CC(C)(Cl)C(Br)CCC(C)(O)C1CCC(C)(C(O)CCCC23CCC(C(C)(O)CCC(Br)C(C)(C)Cl)(O2)O3)O1</smiles>

19 (intricatriol)

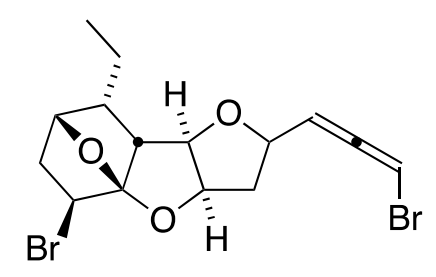

21 (hachijojimallene B)

Figure 3. Structures of new Laurencia sp. halogenated metabolites from Japanese costal waters. 
The Chinese red alga Symphyocladia latiuscula, gathered from Qingdao coastal waters, contains ten new polybrominated phenols, the symphyocladins $\mathrm{H}-\mathrm{Q}\left(22\right.$ - 31) (Figure 4). ${ }^{14}$ A biosynthetic pathway involving the coupling of a quinone methide from 2,3,6-tribromo-4,5-dihydroxybenzyl alcohol, a known natural phenol, and citric acid is proposed, but remains unsupported by experimental evidence.<smiles>CC(=O)CC(Cc1c(Br)c(O)c(O)c(Br)c1Br)=C(C)C(=O)O</smiles>

22, $Z$ (symphyocladin $\mathrm{H}$ ) 23, $E$ (symphyocladin I)<smiles>[R]OC(=O)/C=C(/COC(C)=O)C(C)Cc1c(Br)c(O)c(O)c(Br)c1Br</smiles>

26, $\mathrm{R}=\mathrm{H}$ (symphyocladin $\mathrm{L}$ ) 27, $R=$ Et (symphyocladin $M$ )<smiles>CC(=O)CC(CC(C)=O)CC(=O)c1c(Br)c(O)c(O)c(Br)c1Br</smiles>

29 (symphyocladin O)<smiles>CC(=O)CC(CCOC(C)=O)C(C)=Cc1c(Br)c(O)c(O)c(Br)c1Br</smiles>

24 (symphyocladin $\mathrm{J}$ ) 25 (symphyocladin K)<smiles>CC(=O)C/C(=C\Cc1c(Br)c(O)c(O)c(Br)c1Br)C(=O)O</smiles>

28 (symphyocladin N)<smiles>C=C(Cc1c(Br)c(O)c(O)c(Br)c1Br)C(C)C(=O)OC</smiles>

30, $\mathrm{R}=\mathrm{H}$ (symphyocladin $\mathrm{P}$ )

31, $R=$ Me (symphyocladin $Q$ )

Figure 4. Structures of new Symphyocladia latiuscula polybrominated phenols.

A Japanese sample of the red alga Odonthalia corymbifera afforded the two new bromophenols odonthalol (32) and odonthadione (33), the latter of which contains the cyclopentenedione unit previously unknown in natural products (Figure 5). ${ }^{15}$ Both phenols possess tyrosinase inhibitory and antioxidant activity.

Although naturally occurring organoiodides are rare, ${ }^{2,3,8}$ a collection of the red alga Callophycus sp. from Fiji furnished five novel iodinated meroditerpenes, iodocallophycoic acid A (34) and iodocallophycols A-D (3538), and the related bromophycoic acid $F(39)$ and bromophycoic acid A methyl ester (40) (Figure 6). ${ }^{16}$ lodocallophycoic acid A (34) displays moderate activity against methicillin-resistant Staphylococcus aureus (MRSA) and vancomycin-resistant Enterococcus faecium (VREF) (MIC $=1.4$ and $2.2 \mu \mathrm{g} / \mathrm{mL}$, respectively). This metabolite also potentiates the anti-MRSA activity of oxacillin leading to an 8-fold increase in potency of the latter antibiotic. 
<smiles>COCc1cc(O)c(Oc2c(Cc3c(COC)cc(O)c(O)c3Br)cc(O)c(O)c2Br)c(Br)c1Br</smiles>

32 (odonthalol)<smiles>O=C1C=C(CO)C(=O)C1Cc1cc(O)c(O)c(Br)c1Br</smiles>

33 (odonthadione)

Figure 5. Structures of new Odonthalia corymbifera polybrominated phenols.<smiles>[R7]c1cc([R2])c(O)c(C[C@H]2/C(=C/I)CC[C@H](Br)[C@@]2(C)CC[C@H]2/C(=C/I)CC[C@H](Br)C2(C)C)c1</smiles>

34, $\mathrm{R}^{1}=\mathrm{CO}_{2} \mathrm{H}, \mathrm{R}^{2}=\mathrm{H}$ (iodocallophycoic acid)

35, $R^{1}=R^{2}=B r$ (iodocallophycol A)

36, $R^{1}=B r, R^{2}=I$ (iodocallophycol $B$ )

37, $R^{1}=I, R^{2}=B r$ (iodocallophycol C)

38, $R^{1}=R^{2}=$ I (iodocallophycol $D$ )

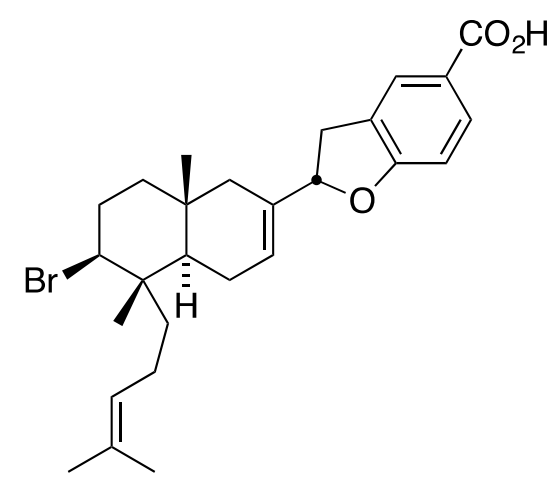

39 (bromophycoic acid F)<smiles>COC(=O)c1ccc2c(c1)C[C@@H](C1(O)CC[C@H]3[C@](C)(CCC=C(C)C)[C@@H](Br)CC[C@]3(C)C1)O2</smiles>

40 (bromophycoic acid A methyl ester)

Figure 6. Structures of new Callophycus sp. halogenated meroditerpenes.

A large collection of polyhalogenated acetogenins was identified in the red alga Ptilonia magellanica collected off the coast of Chile. These included ptilonines A - F (41 - 46), magellenediol (47), and pyranosylmagellanicus $D$ (48) and $E$ (49). The absolute configuration of the previously known 
pyranosylmagellanicus A (not shown) was determined by derivatization with $(R)$ - and $(S)$ - $\alpha$-methoxy- $\alpha$ phenylacetic acids.<smiles>[X]C([X])C(CC(CCC)OC(=O)C(Br)Br)OC(C)=O</smiles>

41, $X=Y=B r$ (ptilonine $A$ ) 42, $\mathrm{X}=\mathrm{Cl}, \mathrm{Y}=\mathrm{Br}$ (ptilonine $\mathrm{B}$ ) 43, $\mathrm{X}=\mathrm{H}, \mathrm{Y}=\mathrm{Br}$ (ptilonine $\mathrm{C}$ ) 44, $\mathrm{X}=\mathrm{H}, \mathrm{Y}=\mathrm{Cl}$ (ptilonine $\mathrm{D}$ )<smiles>CCC[C@H](O)C/C=C(\Cl)C(O)C(Br)Br</smiles>

47 (magellenediol)<smiles>[X]C([X])C(O)CC(CCC)OC(=O)C(Br)Br</smiles>

45, $\mathrm{X}=\mathrm{Y}=\mathrm{Br}$ (ptilonine $\mathrm{E}$ )

46, $\mathrm{X}=\mathrm{Cl}, \mathrm{Y}=\mathrm{Br}$ (ptilonine $\mathrm{F}$ )<smiles>CCC[C@@H]1C[C@@H](OC(C)=O)C(Cl)=C(C(Br)Br)O1</smiles>

48 (pyranosylmagellanicus D)<smiles>CCC[C@@H]1C[C@@H](O)[C@H](O)[C@](O)(C(Br)Br)O1</smiles>

49 (pyranosylmagellanicus E)

Figure 7. Structures of new Ptilonia magellanica halogenated acetogenins.

Five tropical seaweeds, Kappaphycus alvarezii, Padina australis, Sargassum binderi, Sargassum siliquosum, and Turbinaria conoides, emit these well known halocarbons: $\mathrm{CHBr}_{3}, \mathrm{CH}_{2} \mathrm{Br}_{2}, \mathrm{CH}_{3} \mathrm{l}, \mathrm{CH}_{2} \mathrm{I}_{2}, \mathrm{CH}_{2} \mathrm{Brl}, \mathrm{CH}_{2} \mathrm{BrCl}$, $\mathrm{CHBrCl}_{2}$, and $\mathrm{CHBr}_{2} \mathrm{Cl}$. The effect of seawater $\mathrm{pH}$ on these emissions was recently examined, and it was found that decreasing $\mathrm{pH}$ led to an increase in selective halocarbon emissions. ${ }^{18}$

\subsection{Sponges}

Like most marine plants, but unlike fish and marine animals, sponges are anchored to the reef and must employ chemical defense for survival against predation. As we will see, the structural diversity of sponge metabolites is astonishing. It must be noted that the actual origin of some of these metabolites may be bacteria or microalgae associated with the sponge. This point will be visited later. These marine sponge antifouling metabolites were reviewed in 2017. ${ }^{19-21}$ Also reviewed last year were the metabolites from the sponge genus Agelas, ${ }^{22}$ and the cyclic azole-homologated peptides from sponges. ${ }^{23}$

A common structural motif adopted by marine sponges is the pyrrole heterocycle. For example, 32 bromopyrrole alkaloids were isolated from the sponge Stylissa massa collected in Hainan Island, China. Of these metabolites five are new, stylisines A - E (50 - 54), which include the enantiomeric pair 53 and 54 (Figure $8) .^{24}$ 
<smiles>N=C(N)Nc1c2n(c(=O)c3[nH]cc(Br)c13)CCC2</smiles>

50 (stylisine A)<smiles>NC1=NC2=CC(CNC(=O)c3cc(Br)c(Br)[nH]3)OC2=N1</smiles>

52 (stylisine C)<smiles></smiles>

51 (stylisine B)<smiles>NC(=O)C[C@H]1CNC(=O)c2cc(Br)c(Br)n21</smiles>

53 (stylisine D)<smiles>NC(=O)C[C@H]1CNC(=O)c2cc(Br)c(Br)n21</smiles>

54 (stylisine E)

Figure 8. Structures of new Stylissa massa brominated pyrroles.

The sponge Agelas sp. is a fruitful producer of bromopyrrole alkaloids and a recent collection of Agelas sp. from the South China Sea afforded four new dimeric bromopyrrole metabolites, hexazosceptrin (55), agelestes $A$ and $B(56,57)$, and $\left(9 S, 10 R, 9^{\prime} S, 10^{\prime} R\right)$-nakamuric acid (58) (Figure 9). ${ }^{25}$ The absolute configuration of all four metabolites was established. None of these compounds show activity against lymphoma U937 and lung cancer PC9 cells.<smiles>N=C(N)N[C@H]1C(=O)c2nc(N)[nH]c2[C@H]2[C@@H](CNC(=O)c3cc(Br)c[nH]3)[C@H](CNC(=O)c3cc(Br)c[nH]3)[C@@H]21</smiles>

55 (hexazosceptrin)<smiles>[R]OC(=O)[C@@H]1[C@@H](CNC(=O)c2cc(Br)c[nH]2)[C@H](CNC(=O)c2cc(Br)c[nH]2)[C@@H]1C(C)=O</smiles>

56, $\mathrm{R}=\mathrm{H}$ (agelestes $\mathrm{A}$ ) 57, $R=$ Me (agelestes $B$ )<smiles>Nc1ncc([C@@H]2[C@@H](CNC(=O)c3cc(Br)c[nH]3)[C@@H](CNC(=O)c3cc(Br)c[nH]3)[C@H]2C(=O)O)[nH]1</smiles>

$58\left(\left(9 S, 10 R, 9^{\prime} S, 10^{\prime} R\right)\right.$-nakamuric acid)

Figure 9. Structures of new Agelas sp. brominated pyrroles. 
A deep-water (140 m) Palau Topsentia sp. sponge contains two novel brominated indoles, tulongicin A (59) and dihydrospongotine $C$ (60), in addition to two known analogues (Figure 10). ${ }^{26}$ Their absolute configuration was determined, and both metabolites display strong antimicrobial activity against Staphylococcus aureus (MIC $=1.2-3.7 \mu \mathrm{g} / \mathrm{mL})$.<smiles>Brc1ccc2c(C(C3=NC[C@H](c4c[nH]c5cc(Br)ccc45)N3)c3c[nH]c4cc(Br)ccc34)c[nH]c2c1</smiles>

59 (tulongicin A)<smiles>O[C@H](C1=NC[C@H](c2c[nH]c3cc(Br)ccc23)N1)c1c[nH]c2cc(Br)ccc12</smiles>

60 (dihydrospongotine C)

Figure 10. Structures of new Topsentia sp. brominated indoles.

An examination of the Indonesian sponge Oceanapia sp. yielded the indole metabolite 6-bromo-8-ketoconicamin A (61), which displays strong activity against the human pancreatic cancer cell line PANC-1 $($ IC $50=$ $1.5 \mu \mathrm{M}){ }^{27}$ Four novel thiazole containing biakamides A - D (62 - 65) were isolated from another Indonesian sponge, Petrosaspongia sp (Figure 11). These unique polyketides are also active against PANC-1 (IC $50=0.5-$ $4.0 \mu \mathrm{M}){ }^{28}$ Total syntheses of all possible stereoisomers from the optically pure monoprotected 2,4-dimethyl1,5-diol established the absolute configurations of the two secondary methyl groups.<smiles>C[N+](C)(C)CC(=O)c1c[nH]c2cc(Br)ccc12</smiles>

61 (6-bromo-8-keto-conicamin A)<smiles>C/C(=C\[C@H](C)C[C@H](C)CC/C(=C/Cl)CCCN(C)C(=O)C[C@H](C)O)C(=O)N(C)Cc1nccs1</smiles>

62, $9 E$ (biakamide A)

63, $9 Z$ (biakamide B)<smiles>COC(C)=CC(=O)N(C)CCCC(=CCCl)CC[C@H](C)C[C@H](C)C=C(C)C(=O)N(C)Cc1nccs1</smiles>

64, $9 E$ (biakamide C) 65, $9 Z$ (biakamide D)

Figure 11. Structures of new Indonesian sponge metabolites. 
Sponges have a proclivity for incorporating the bromotyrosine unit in their metabolites ${ }^{2,3}$ and several new examples were reported in 2017. The Madagascan sponge Amphimedon sp. contains amphimedonoic acid (66) and psammaplysene E (67), along with the known 3,5-dibromo-4-methoxybenzoic acid. ${ }^{29}$ Neither compound is active against human epidermoid carcinoma KB cells $\left(I C_{50}>10 \mu \mathrm{g} / \mathrm{mL}\right)$. A sponge from Western Australia, Pseudoceratina cf. verrucosa, yielded pseudoceratinamide A (68) and B (69) and the enantiomer 70 of a previously known bromotyrosine (Figure 12 ). ${ }^{30}$<smiles>CN(C)CCCOc1ccc(C(=O)O)cc1Br</smiles>

66 (amphimedonoic acid)<smiles>[R]c1cc(CCNC(=O)C2=NO[C@]3(C=C(Br)C(OC)=C(Br)[C@@H]3O)C2)cc(Br)c1O</smiles>

68, $R=B r$ (pseudoceratinamide $A$ )

69, $\mathrm{R}=\mathrm{H}$ (pseudoceratinamide $B$ )<smiles>COc1c(Br)cc(/C=C/C(=O)NCCc2cc(Br)c(OCCCN(C)C)c(Br)c2)cc1Br</smiles>

67 (psammaplysene E)<smiles>COC1=C(Br)[C@@H](O)[C@]2(C=C1Br)CC(C(=O)NCCCC(=O)O)=NO2</smiles>

70

Figure 12. Structures of new sponge bromotyrosines.

The Indonesian sponge lotrochota cf. iota yielded seven new halogenated tyrosines, enisorines A - E (71 75), (+)-1-O-methylhemibastadinol 2 (76), and (+)-1-O-methylhemibastadinol 4 (77) (Figure 13). ${ }^{31}$ All seven metabolites inhibit T3SS-dependent YopE secretion, which is a virulence factor employed by many Gramnegative pathogens that injects bacterial effector proteins into host cells to negate host cell defenses.<smiles>[X]c1cc(CCN([Y19])C(=O)CC)cc([X])c1OCCCN([R])C(=O)Cc1ccc(O)cc1</smiles>

71, $\mathrm{R}=\mathrm{H}, \mathrm{X}=\mathrm{Br}, \mathrm{Y}=\mathrm{H}$ (enisorine $\mathrm{A}$ )

72, $R=H, X=I, Y=H$ (enisorine $B$ )

73, $\mathrm{R}=\mathrm{Me}, \mathrm{X}=\mathrm{Br}, \mathrm{Y}=\mathrm{H}$ (enisorine $\mathrm{C}$ )

74, $\mathrm{R}=\mathrm{H}, \mathrm{X}=\mathrm{Br}, \mathrm{Y}=\mathrm{Br}$ (enisorine $\mathrm{D}$ )

75, $\mathrm{R}=\mathrm{H}, \mathrm{X}=\mathrm{I}, \mathrm{Y}=\mathrm{Br}$ (enisorine $\mathrm{E}$ )<smiles>[X]c1cc(CCNC(=O)C(O)Cc2cc(Br)c(OC)c(Br)c2)ccc1O</smiles>

76, $\mathrm{X}=\mathrm{Br}((+)-1-O$-methylhemibastadinol 2) 77, $X=I \quad((+)-1-O-$ methylhemibastadinol 4)

Figure 13. Structures of new lotrochota cf. iota halogenated tyrosines. 


\subsection{Corals}

Whereas a few hard (stony) corals liberate organohalogen metabolites, soft corals (octocorals, sea fans, gorgonians) are extraordinarily generous producers of halogen-containing metabolites. ${ }^{2,3}$ These stunning marine animals, gently swaying in the reef currents, are both a delight for the scuba diver and a treasure trove for the marine natural products chemist seeking new metabolites.

The briarane (bicyclo[8.4.0]) diterpenoid carbon skeleton is pervasive in soft corals, as more than 600 examples are known from marine octocorals and gorgonians, many of which contain chlorine. ${ }^{2-4} \mathrm{~A}$ collection of the octocoral Briareum excavatum from Taiwanese waters furnished three new briarenols, one of which, briarenol E (78), contains chlorine. ${ }^{32}$ The gorgonian coral Junceella fragilis from Hainan Island, China, contains four pairs of chlorinated briarane diterpenes, five of which are new (79-83) (Figure 14). ${ }^{33}$ Interestingly, these pairs of isomers undergo acetyl migration (i.e., $\mathbf{8 0} \rightleftarrows \mathbf{8 1}$, and $\mathbf{8 2} \rightleftarrows \mathbf{8 3}$ ), which was observed for the first time. The acetyl migration of $\mathbf{7 9}$ yields the previously known fragilide J (2-deacetylpraelolide), which is also present inn this coral. All of these metabolites inhibit the production of nitric oxide in RAW 264.7 cells.

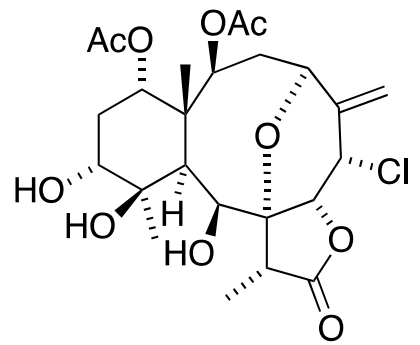

78 (briarenol E)

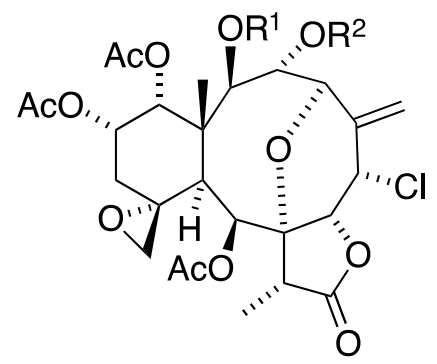

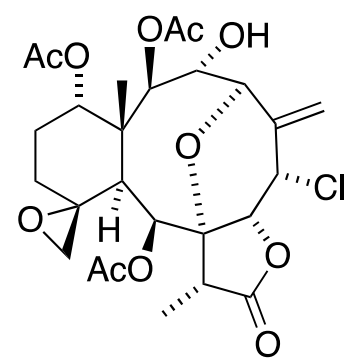

79 (3-deacetylpraelolide)

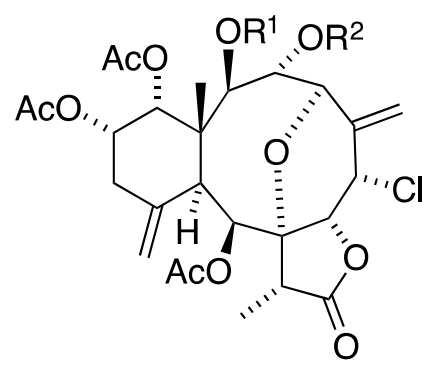

80, $R^{1}=A c, R^{2}=H \quad\left(13-\alpha\right.$-acetoxy-3-deacetylpraelolide) 82, $R^{1}=A c, R^{2}=H \quad(13$ - $\alpha$-acetoxy-3-deacetyljunceellin) 81, $R^{1}=H, R^{2}=A c$ (13- $\alpha$-acetoxy-2-deacetylpraelolide) $83, R^{1}=H, R^{2}=A c$ (13- $\alpha$-acetoxy-2-deacetyljunceellin)

Figure 14. Structures of new briarane chlorinated diterpenoids.

In addition to several known diterpenoids, another collection of Junceella fragilis from Hainan Island by this same research group yielded seventeen new diterpenoids, ten of which contain chlorine (84 - 93) (Figure 15). ${ }^{34}$ Fragilolides D (86), G (89), and $P(\mathbf{9 3})$ are inhibitory towards hepatitis $B$ e antigen (HBeAg), but not active against the expression of hepatitis B surface antigen (HBsAg). None of these metabolites are cytotoxic in a panel of tumor cell lines. 


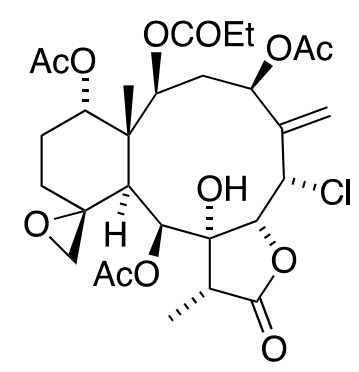

84 (fragilolide B)

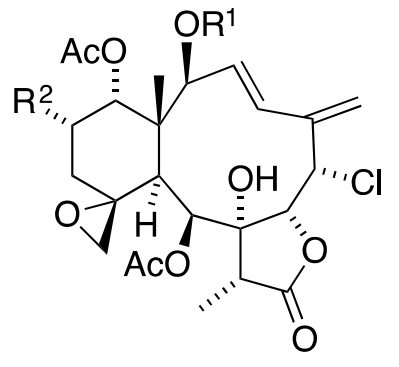

85, $R^{1}=$ COEt, $R^{2}=$ OAc (fragilolide C) 87 (fragilolide E)

86, $R^{1}=A c, R^{2}=H$ (fragilolide $D$ )

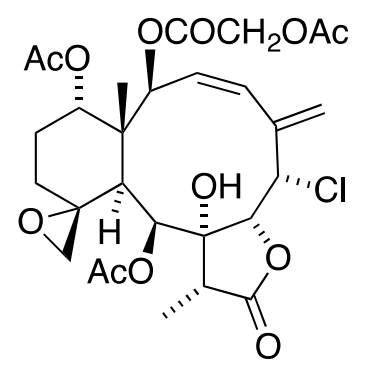

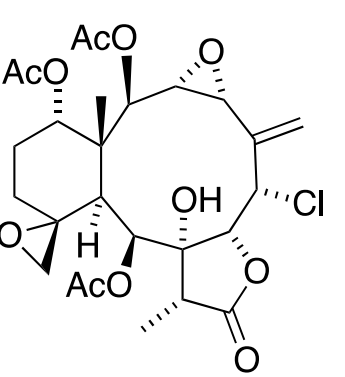

90 (fragilolide $\mathrm{H}$ )

88 (fragilolide F)

89 (fragilolide G)

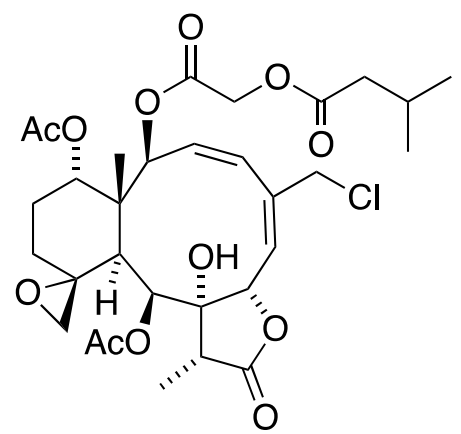

92 (fragilolide O)

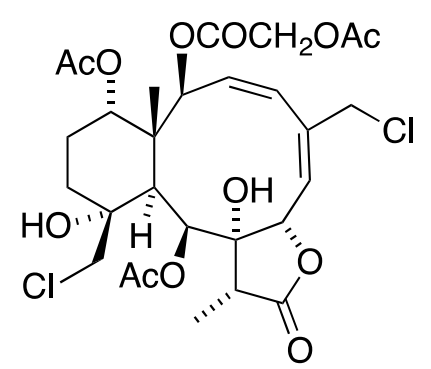

93 (fragilolide $\mathrm{P}$ )

Figure 15. Structures of new briarane chlorinated diterpenoids from Junceella fragilis.

\subsection{Tunicates}

Tunicates (ascidians, sea squirts) belong to subphyllum Urochordata (or Tunicata) of the phyllum Chordata, Class Ascidiacea. Like sponges, tunicates are filter feeders and rely on chemical defense for survival. They may be solitary or colonial marine animals. Some 3,000 species of tunicates have been described, ${ }^{35}$ and a recent review is available. ${ }^{36}$

The Korean tunicate Pseudodistoma antinboja yielded four new cadiolides J-M (94-97) (Figure 16), ${ }^{37}$ the only halogenated tunicate metabolites described in 2017. 
<smiles>[R9]Oc1c([R])cc(/C=C2\OC(=O)C([C@H](O)c3cc(Br)c(O[R8])c(Br)c3)=C2c2cc([R])c(O)c(Br)c2)cc1[R7]</smiles>

94, $R^{1}=R^{2}=B r, R^{3}=R^{5}=M e, R^{4}=H$ (cadiolide $J$ )

95, $R^{1}=R^{2}=B r, R^{3}=R^{4}=H, R^{5}=M e$ (cadiolide $K$ )

96, $R^{1}=R^{3}=H, R^{2}=R^{4}=B r, R^{5}=M e$ (cadiolide $L$ )

97, $R^{1}=R^{2}=R^{4}=B r, R^{3}=R^{5}=H$ (cadiolide $M$ )

Figure 16. Structures of new brominated phenols from Pseudodistoma antinboja.

\subsection{Bryozoans}

Unlike the majestic soft corals and brightly colored sponges, bryozoans (Phylum Bryoza = Ectoprocta) are nondescript "moss animals" that are ignored by scuba divers and snorkelers (in my experience). Nevertheless, these inauspicious marine animals produce remarkably complex halogen-containing metabolites. ${ }^{2,3}$

The Arctic bryozoan Securiflustra securifrons has furnished securamines H - J (98 - 100) (Figure 17). ${ }^{38}$ These halogenated indole-imidazole alkaloids were found in bryozoans living off the coast of Hjelms $\varnothing$ ya, Norway. Securamines $\mathrm{H}$ and I are cytotoxic against these human cancer cell lines A2058 (melanoma), HT-29 (colon adenocarcinoma), and MCF-7 (breast adenocarcinoma) with IC 50 MM values of $1.4-2.7,1.9-2.5$, and 2.1 -2.4 , respectively. Securamine $\mathrm{J}(\mathbf{1 0 0})$ is inactive in all three cell lines $\left(\mathrm{IC}_{50}>50 \mu \mathrm{M}\right)$, and securamine $\mathrm{H}(\mathbf{9 8})$ is slightly more active than securamine I (99).

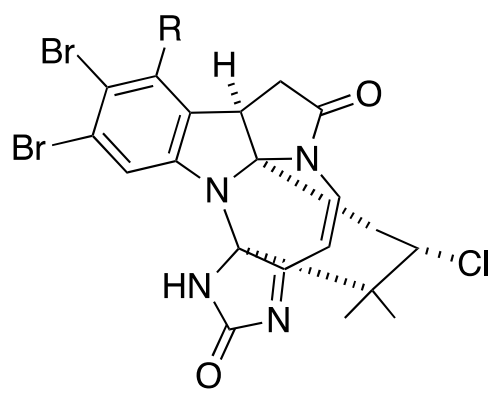

98, $\mathrm{R}=\mathrm{Br}$ (securamine $\mathrm{H}$ ) 99, $\mathrm{R}=\mathrm{H}$ (securamine $\mathrm{I}$ )

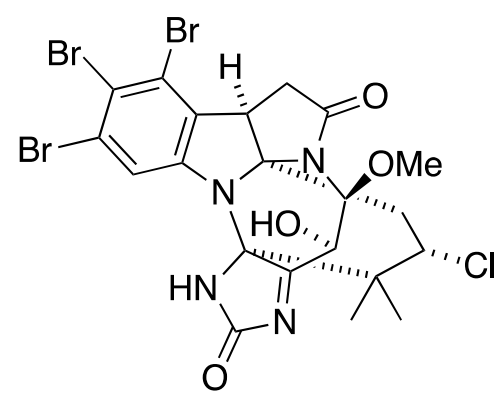

100 (securamine $\mathrm{J}$ )

Figure 17. Structures of new halogenated indole-imidazoles from Securiflustra securifrons.

Two new brominated indoles, terminoflustrindoles B (101) and C (102), were extracted from and identified in the bryozoan Terminoflustra membranaceatruncata that was collected in the White Sea (Figure 18). ${ }^{39}$ 


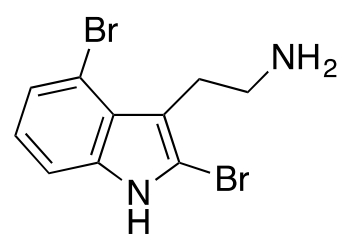

101 (terminoflustrindole B)

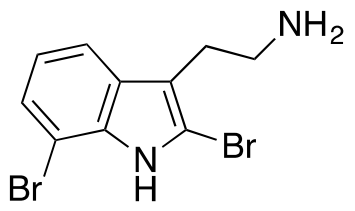

102 (terminoflustrindole C)

Figure 18. Structures of new bromoindoles from Terminoflustra membranaceatruncata.

\subsection{Marine fungi}

A relatively new source of metabolites is marine fungi and several examples were reported in 2017.

For example, the fungus Hansfordia sinuosae, found with the sponge Niphates sp. From the South China Sea, afforded the novel chlorinated resorcinol hansfordiols $\mathrm{H}$ - J (103 - 105), in addition to seven nonchlorinated analogues. ${ }^{40}$ Hansfordiols $\mathrm{H}$ and I show good antioxidant activity comparable to Trolox, but no antibacterial activity or cytotoxicity against several cell lines. The fungus Penicillium sp. SCS-KFD09, found growing on the marine worm Sipunculus nudus, is the source of the six new meroterpenoids, two of which contain chlorine, chrodrimanins $\mathrm{K}(\mathbf{1 0 6})$ and $L(\mathbf{1 0 7}){ }^{41}$ The former meroterpenoid displays influenza $A$ virus (anti-H1N1) activity $\left(\mathrm{IC}_{50}=74 \mu \mathrm{M}\right)$, compared to the positive control ribavirin $\left(\mathrm{IC}_{50}=103 \mu \mathrm{M}\right)$. Of five new meroterpenoids isolated from a Penicillium sp. SCS-KFD09 fungus living with the marine worm Sipunculus nudus from Haikou Bay, China, one contains chlorine: the unusual trichlorinated chrodrimanin O (108) (Figure 19). ${ }^{42}$ It displays inhibition of protein tyrosine phosphatase $1 \mathrm{~B}$ (PTP1B) $\left(\mathrm{IC}_{50}=71.6 \mu \mathrm{M}\right)$, but no cytotoxicity towards three tumor cell lines (A549, HepG2, and HeLa) at $10 \mu \mathrm{M}$.<smiles>[R]c1c(O)cc(CCC(=O)O)c(Cl)c1O</smiles>

103, $\mathrm{R}=\mathrm{H}$ (hansfordiol $\mathrm{H}$ ) 104, $\mathrm{R}=\mathrm{Cl}$ (hansfordiol $\mathrm{J}$ )<smiles>CC(=O)CCc1cc(O)c(Cl)c(O)c1Cl</smiles>

105 (hansfordiol K)<smiles>C[C@H]1Cc2c3c(c(Cl)c(O)c2C(=O)O1)O[C@]1(C3)C(O)C[C@H]2C(C)(C)C(=O)CC[C@]2(C)[C@H]1C</smiles>

106 (chrodrimanin K)<smiles>C[C@H]1Cc2c3c(c(Cl)c(O)c2C(=O)O1)O[C@]1(O3)C(O)C[C@H]2C(C)(C)C(=O)[C@@H](Cl)C[C@]2(C)[C@H]1C</smiles>

107 (chrodrimanin L)<smiles>C[C@H]1Cc2c3c(c(O)c(Cl)c2C(=O)O1)[C@@]1(O)[C@@H](O)C[C@H]2C(C)(C)C(=O)C(Cl)(Cl)C[C@]2(C)[C@@H]1C3</smiles>

108 (chrodrimanin O)

Figure 19. Structures of new chlorinated metabolites from marine fungi.

Another set of meroterpenoids, the chartarolides A - C (109 - 111), was identified in the fungus Stachybotrys chartarum WGC-25C-6, which is found with the sponge Niphates recondite (Figure 20). ${ }^{43}$ All three compounds exhibit significant antitumor activity; for example, chartarolide A shows inhibition of these 
human cell lines: HCT-116 (colon, $I_{50}=1.9 \mu \mathrm{M}$ ), HepG2 (liver, IC $\mathrm{IC}_{50}=1.8 \mu \mathrm{M}$ ), BGC-823 (gastric, $\mathrm{IC}_{50}=1.3 \mu \mathrm{M}$ ), $\mathrm{NCl}-\mathrm{H} 1650$ (lung, IC $\mathrm{IC}_{50}=5.5 \mu \mathrm{M}$ ), A2780 (ovarian, IC $\mathrm{C}_{50}=1.5 \mu \mathrm{M}$ ), MCF7 (ovarian, $\mathrm{IC}_{50}=1.4 \mu \mathrm{M}$ ). Chartarolides $\mathrm{A}$ and $B$ also inhibit several tumor-related protein kinases $\left(\mathrm{IC}_{50}=2.6-20.3 \mu \mathrm{M}\right)$.

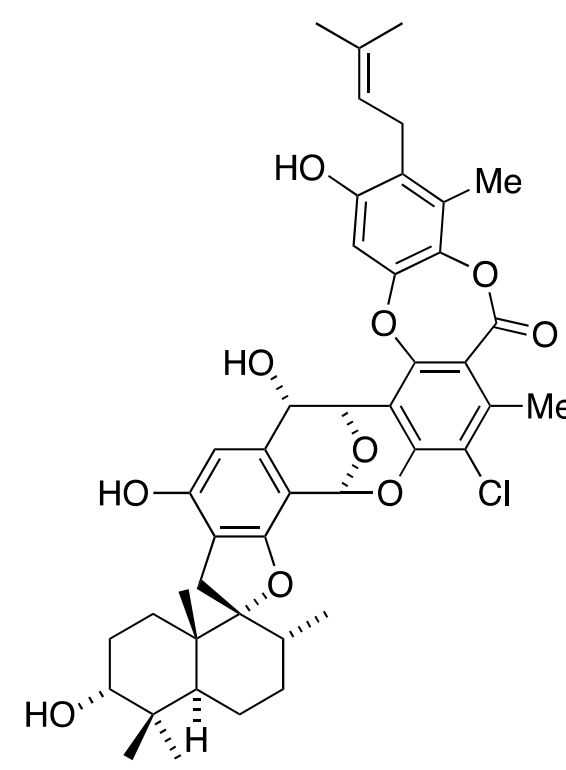

109 (chartarolide A)

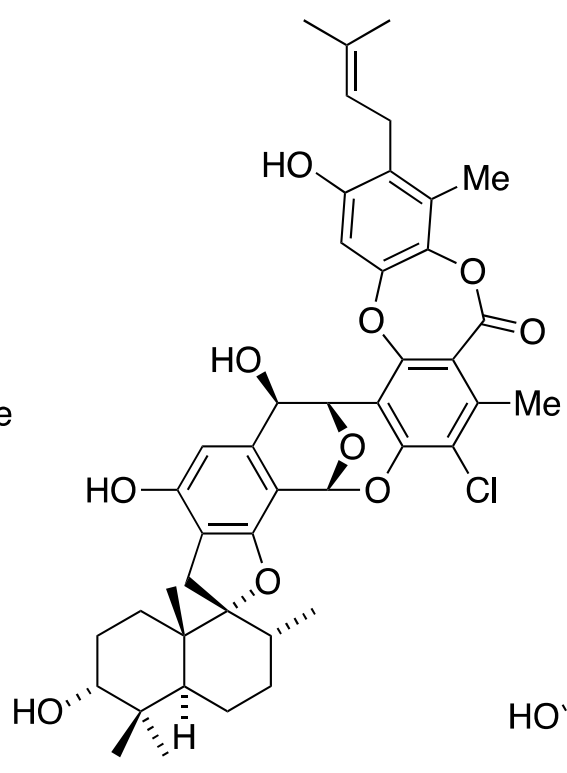

110 (chartarolide B)

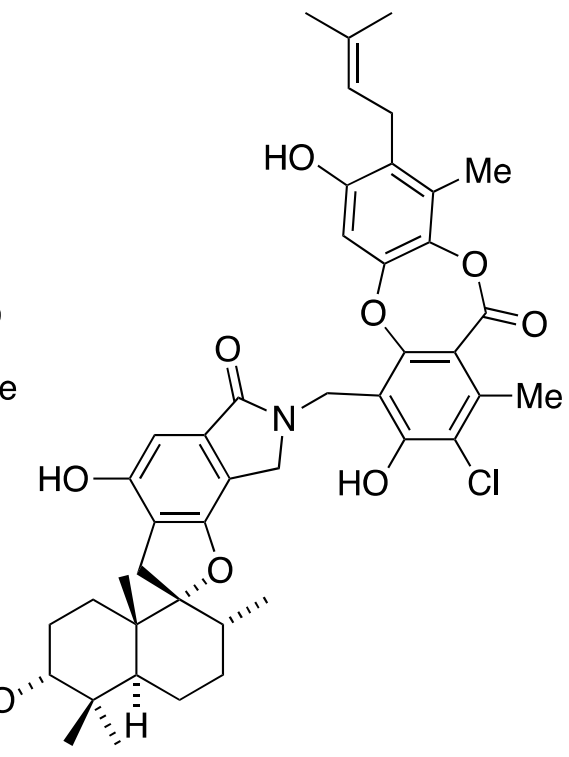

111 (chartarolide C)

Figure 20. Structures of new chlorinated metabolites from Stachybotrys chartarum WGC-25C-6.

The marine fungus Penicillium sp. F37 is found with the Brazilian coastal sponge Axinella corrugata and produces arvoredol (112), a novel chlorinated polyketide that inhibits biofilm formation on the sponge. ${ }^{44}$ This $^{4}$ metabolite also inhibits biofilm formation of the human pathogen Staphylococcus epidermidis without serving as an antibiotic. The mangrove soil-derived fungus Penicillium janthinellum HK1-6 has yielded two chlorinecontaining azaphilones, penicilones $C(\mathbf{1 1 3})$ and $D(\mathbf{1 1 4}) .^{45}$ Both compounds show potent anti-MRSA (Staphylococcus aureus ATCC 43300 and ATCC 33591) activity (MIC 3.13-6.25 $\mathrm{gg} / \mathrm{mL}$ ). Penicilone D also displays strong activity against vancomycin-resistant Enterococcus faecalis. This suggests that the penicilones (including the two non-chlorinated penicilones $A$ and $B$ ) may have the capability to circumvent antibiotic crossresistance. Another marine-derived Penicillium sp. 5CS10 sof 101 fungus from a South China Sea sediment furnished three new chlorinated emodacidamides $C$ (115), $F(\mathbf{1 1 6})$, and $G(\mathbf{1 1 7})$, in addition to five nonchlorinated analogues (Figure 21). 
<smiles>CCC(C)[C@H](O)[C@@](C)(O)/C=C/c1cc2c(o1)[C@H](CO)[C@H](OC(C)=O)[C@@](C)(Cl)C2=O</smiles>

112 (arvoredol)<smiles>CCCCCCC(C)/C=C(\C)C(=O)O[C@]1(C)C(=O)C2=COC(C3=C(C)CC(O)CC3=O)=CC2=C(Cl)C1=O</smiles>

113 (penicilone C)<smiles>CCCCCCC(C)/C=C(\C)C(=O)O[C@@]1(C)C(=O)C2=COC(c3c(C)cccc3O)=CC2=C(Cl)C1=O</smiles>

114 (penicilone D)

116 (emodacidamide $\mathrm{F}$ )<smiles>CCC(C)[C@H](NC(=O)c1cc(O)c2c(c1)C(=O)c1cc(O)c(Cl)c(O)c1C2=O)C(=O)O</smiles><smiles>CC(C)[C@H](NC(=O)c1cc(O)c2c(c1)C(=O)c1cc(O)c(Cl)c(O)c1C2=O)C(=O)O</smiles>

115 (emodacidamide C)<smiles>CC(C)C[C@H](NC(=O)c1cc(O)c2c(c1)C(=O)c1cc(O)c(Cl)c(O)c1C2=O)C(=O)O</smiles>

117 (emodacidamide G)

Figure 21. Structures of new chlorinated metabolites from marine fungi.

\subsection{Marine bacteria}

Bacteria live everywhere, including in the marine environment. A few halogenated bacterial metabolites from the oceans were described in 2017. Cultures of the marine bacterium Pseudovibrio denitrificans Ab134, which were isolated from the sponge Arenosclera brasiliensis, yielded several known bromotyrosine-derived alkaloids that were previously only isolated from marine sponges. ${ }^{47}$ This work shows for the first time that bromotyrosine-derived alkaloids can be biosynthesized by a marine bacterium. The isolated or spectroscopically identified alkaloids are fistularin-3, 11-hydroxyaerothionin, verongidoic acid, aerothionin, homopurpuroceratic acid B, purealidin L, and aplysinamisine II, all previously isolated only from Verongida sponges. $^{2,3}$

A Palau sediment sample yielded a new streptomycete strain that produces marinocyanins A - F (118 123), which are novel brominated phenazinone meroterpenoids (Figure 22). ${ }^{48}$ Marinocyanin $A$ is the most potent antifungal agent of the six marinocyanins against amphotericin-resistant Candida albicans (MIC $=0.95$ $\mu \mathrm{M})$. Both marinocyanins $A$ and $B$ display potent cytotoxicity against HCT-116 human colon carcinoma $\left(I_{50}=\right.$ 0.049 and $0.029 \mu \mathrm{M}$, respectively). 
<smiles>CC1=C(Cn2c3ccc(Br)c(=O)c-3nc3ccccc32)CCC(C)(C)C1</smiles>

118 (marinocyanin A)<smiles>CC1=C(Cn2c3ccc(Br)c(=O)c-3nc3ccccc32)CCC(C)(CO)C1</smiles>

121 (marinocyanin D)<smiles>CC(C)=CCn1c2ccc(Br)c(=O)c-2nc2ccccc21</smiles>

119 (marinocyanin B)<smiles>CC1=C(Cn2c3ccc(Br)c(=O)c-3nc3ccccc32)CCC(C)(C)C1O</smiles>

122 (marinocyanin E)<smiles>CC(C)=CC(=O)OCC1=C(Cn2c3ccc(Br)c(=O)c-3nc3ccccc32)CCC(C)(C)C1</smiles>

120 (marinocyanin C)<smiles>CC1=C(Cn2c3ccc(Br)c(=O)c-3nc3ccccc32)C(O)CC(C)(C)C1</smiles>

123 (marinocyanin F)

Figure 22. Structures of new brominated metabolites from marine bacteria.<smiles>COc1c(Cl)cc(/C=C(\O)C(=O)N[C@H](C(=O)N[C@@H](CC(C)C)C(=O)N2C(C(=O)N[C@@H](CC(C)C)C(=O)N(O)[C@H]3C(=O)N4C(C)C[C@H]4CC3C)C[C@@H](OC(C)=O)[C@H]2C)[C@@H](C)O)cc1Cl</smiles>

124 (bonnevillamide A)<smiles>[R]C1C[C@H](C(=O)N[C@@H](CC(C)C)C(=O)N(O)[C@@H](C(=O)N2CCC[C@H]2C(=O)O)C(C)C)N(C(=O)[C@H](CC(C)C)NC(=O)[C@H](NC(=O)/C(O)=C/c2cc(Cl)c(OC)c(Cl)c2)[C@@H](C)O)[C@H]1C</smiles>

125, $\mathrm{R}=\mathrm{OH}$ (bonnevillamide $\mathrm{B}$ )

126, $R=$ OAc (bonnevillamide $C$ )

Figure 23. Structures of new chlorinated heptapeptides from Streptomyces sp. GSL-6B.

A sediment sample from the Great Salt Lake, Utah, contains Streptomyces sp. GSL-6B that afforded three heptapeptides, the bonnevillamides A - C (124 - 126) (Figure 23). ${ }^{49}$ These novel natural products feature 
unprecedented non-proteinogenic amino acids, and all three contain the bonnevillic acid unit (3-(3,5-dichloro4-methoxyphenyl)-2-hydroxyacrylic acid). Bonnevillamide A (124) has the extremely rare 4-methylazetidine-2carboxylic acid methyl ester moiety. These metabolites have no antimicrobial activity, but bonnevillamide $B$ (125) modulates heart growth and cardiac function in zebrafish embryo.

\subsection{Cyanobacteria}

As of 2009 more than 1,000 natural products were identified in cyanobacteria, also known as blue-green algae. $^{50,51}$ Many of these organisms contain organochlorines and some are highly toxic to humans. ${ }^{2,3}$ For example, Nostoc cyanobacteria are well recognized as a threat to humans when they infest drinking water. ${ }^{52,53}$ The frequent infestations of Lake Erie by Microcystis aeruginosa cyanobacteria result in serious health concerns. $^{54}$

The global marine cyanobacterium Trichodesmium thiebautii (order Oscillatoriales) collected from a bloom near Padre Island, Texas, in the Gulf of Mexico afforded trichophycin A (127). ${ }^{55}$ This novel metabolite exhibits moderate cytotoxicity against Neuro-2A and HCT-116 cells ( $E C_{50}=6.5$ and $11.7 \mu \mathrm{M}$, respectively). Another collection of a Trichodesmium bloom from the Gulf of Mexico yielded the dichlorinated polyketide trichothiazole A (128). ${ }^{56}$ This metabolite expresses moderate cytotoxicity towards Neuro-2A cells $\left(E_{50}=13.3\right.$ $\mu \mathrm{M})$. The Panamanian cyanobacterium cf. Symploca sp. produces the novel gem-dichlorovinylidene containing caracolamide A (129) (Figure 24). ${ }^{57}$ Although not cytotoxic to $\mathrm{NCl}-\mathrm{H} 460$ human non-small-cell lung cancer cells $\left(\mathrm{IC}_{50}>10 \mu \mathrm{M}\right)$, caracolamide $A$ has calcium influx and calcium channel oscillation modulatory activity as low as 10 pM. Its structure was confirmed by synthesis from 2-phenethylamine.

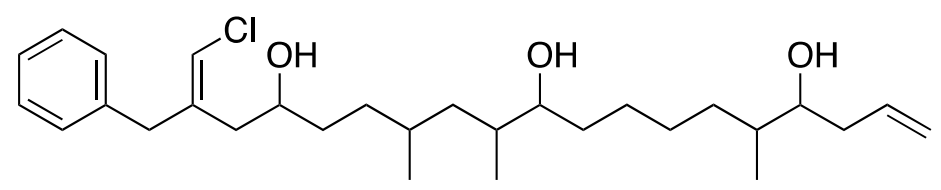

127 (trichophycin A)

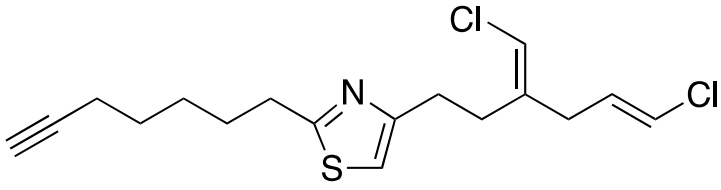

128 (trichothiazole A)

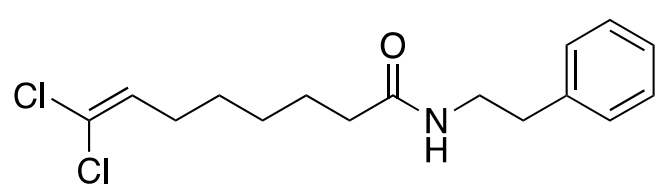

129 (caracolamide A)

Figure 24. Structures of new chlorinated metabolites from cyanobacteria.

A Malaysian cyanobacterium, Moorea bouillonii, contains the novel chlorinated fatty acid amides columbamides D (130) and E (131), the structures of which were confirmed by total synthesis of all four stereoisomers (of 130). ${ }^{58}$ Subsequent chiral-phase HPLC determined the absolute configuration. These two (synthetic) compounds are noncytotoxic at $22 \mu \mathrm{M}$ to MCF7 (breast) and H460 (lung) human cancer cells. An examination of Moorea producens from Okinawa revealed three new malyngamides, 132 - 134 (Figure 25). ${ }^{59}$ These compounds stimulated glucose uptake in cultured $\mathrm{L} 6$ myotubes. 
<smiles>[R]C(Cl)CCCCCCC[C@H](Cl)CCCC/C=C/CCC(=O)N([14CH3])C(CO)CO</smiles>

130, $\mathrm{R}=\mathrm{H}(10 R, 20 R)$ (columbamide $\mathrm{D})$

131, $\mathrm{R}=\mathrm{Cl}$ (columbamide $\mathrm{E}$ )<smiles>CCCCCCC[C@H](C/C=C/CCC(=O)NC/C(=C/Cl)C1C(=O)[C@H](OC(C)=O)C[C@@H](O)[C@]1(C)O)OC</smiles>

132, $\mathrm{R}=\mathrm{Ac}(6,8$-di-O-acetylmalyngamide 2$)$

133, $\mathrm{R}=\mathrm{H}$ (6-O-acetylmalyngamide 2$)$<smiles>CCCCCCC[C@H](CC=CCCC(=O)NCC(=CCl)C12OC1C[C@@H](O)[C@H](C)C2=O)OC</smiles>

134 ( $N$-demethyl-isomalyngamide 1$)$

Figure 25. Structures of new chlorinated metabolites from Moorea sp. cyanobacteria.

An Okeania sp. of cyanobacteria from the Red Sea afforded two new chlorinated lyngbyabellins 0 (135) and $\mathrm{P}(\mathbf{1 3 6})$ in addition to several previously known analogues (Figure 26). ${ }^{60}$ Both compounds display strong antifouling activity against the barnacle Amphibalanus amphitrite $\left(\mathrm{EC}_{50}=0.38-0.73 \mu \mathrm{M}\right)$, and lyngbyabellin $\mathrm{P}$ (136) has potent inhibitory action against MCF-7 breast cancer cells $\left(\mathrm{Gl}_{50}=9 \mu \mathrm{M}\right)$.<smiles>CC(=O)c1csc([C@H](OC(=O)[C@H](C)[C@H](CCCC(C)(Cl)Cl)OC(=O)c2csc([C@H](O)CO)n2)C(C)(C)O)n1</smiles>

135 (lyngbyabellin O)<smiles></smiles>

136 (lyngbyabellin P)

Figure 26. Structures of new chlorinated metabolites from Okeania sp. cyanobacteria. 
A bloom of Lyngbya sp. cyanobacteria growing in the Kemp Channel in the Florida keys yielded kempopeptin C (137). ${ }^{61}$ This novel cyclic depsipeptide shows antiproteolytic activity against trypsin, plasmin, and matriptase $\left(\mathrm{IC}_{50}=0.19,0.36\right.$, and $0.28 \mu \mathrm{M}$, respectively). A rare brominated cyclodepsipeptide, odobromoamide (138), was characterized from the cyanobacterium Okeania sp. found off the coast of Odo, Okinawa (Figure 27). ${ }^{62}$ This metabolite is active against HeLa S3 cells (IC $\left.50=0.31 \mu \mathrm{M}\right)$.

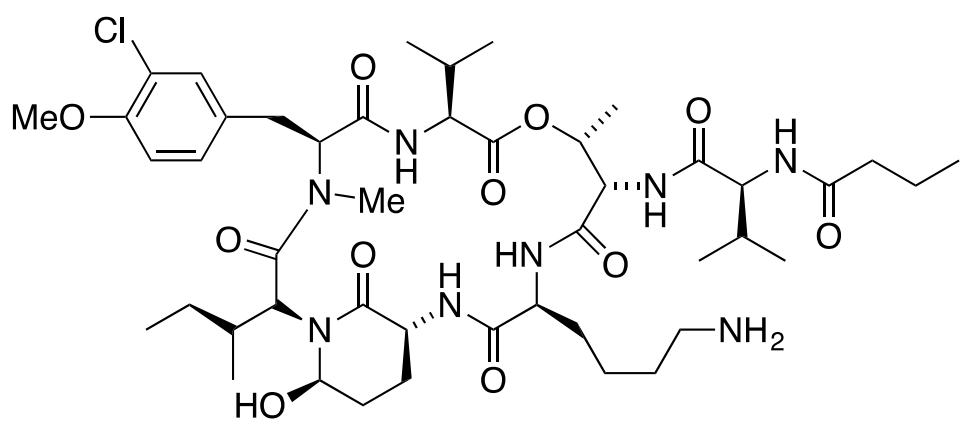

137 (kempopeptin C)

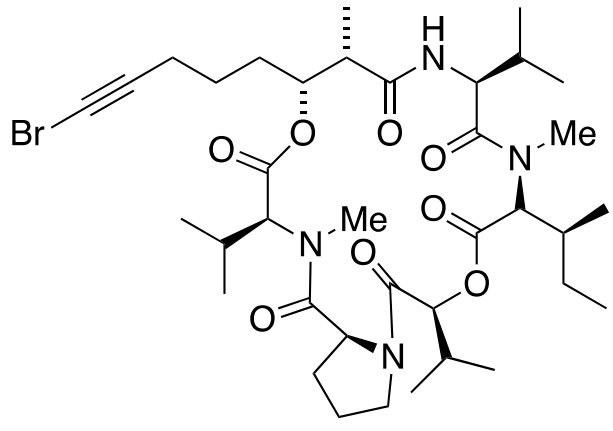

138 (odobromoamide)

Figure 27. Structures of new halogenated metabolites from Lyngbya sp. and Okeania sp. cyanobacteria.

\subsection{Other marine organisms}

Marine brittle stars (Ophiuroidea) are a very large group of reclusive, solitary echinoderms that inhabit the world's oceans. They are typically found hiding under rocks.

A brittle star, Ophionereis reticulata, from the coast of Brazil contains two known chamigrene sesquiterpenes in addition to the novel acetyl isoobtusadiene (139). ${ }^{63}$ The known metabolites found in this animal are elatol and isoobtusadiene, which are common in Laurencia red algae, suggesting a dietary origin for these compounds. The halogenated diterpene dolabellol A (140) was characterized from the opisthobranch Dolabella auricularia found living off the Japanese coast (Figure 28). ${ }^{64}$ The absolute configuration of 140 was established by a combination of spectroscopy, chemical degradation, and X-ray crystallography. As in the previous study, it is suggested that this animal acquires dolabellol A from its algae diet. ${ }^{65}$ Accordingly, dolabellol $A$ is structurally similar to the metabolites obtusadiol, rogioldiol A, laurenditerpenol, and 14bromoobtus-1-ene-3,11-diol, all of which are found in the algae on which Dolabella auricularia feeds.

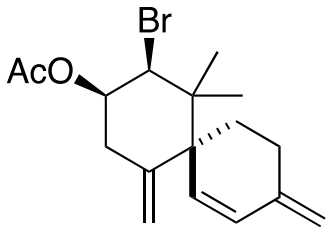

139 (acetyl isoobtusadiene)

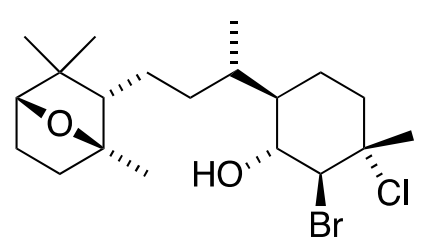

140 (dolabellol A)

Figure 28. Structures of new halogenated metabolites from marine animals.

\subsection{Terrestrial plants}

Lacking the huge concentration of halide (i.e., chloride, bromide) in the oceans, terrestrial organisms manufacture far fewer halogen-containing metabolites than their marine counterparts. ${ }^{2,3}$ Nevertheless, last year several new examples of organochlorine compounds in terrestrial plants, fungi, and bacteria were reported. An excellent review of chlorinated plant steroids and their biological activities has appeared. ${ }^{66} \mathrm{~A}$ 
series of steroidal withanolides, including eleven new examples and two known chlorine-containing ones, were isolated from the plant Physalis peruviana L. (Solanaceae), and were evaluated for their cytotoxicity against prostate and renal cancer cells. ${ }^{67}$ The two known chlorinated examples (not shown) physalolactone and 4-deoxyphysalolactone ${ }^{2}$ are inactive.

The small shrub Uvaria alba Merr. from Luzon Island, Philippines, and reported to have anti-infective and cytotoxic activities, ${ }^{68}$ contains two novel chlorine-containing polyoxygenated seco-cyclohexenes, albanols $A$ (141) and B (142). ${ }^{69}$ Both albanols show modest activity against Mycobacterium tuberculosis $\mathrm{H}_{37} \mathrm{Rv}$ (MIC = 26 $38 \mu \mathrm{M})$, and albanol A exhibits cytostatic activity towards HeLa cells. A collection of the traditional medicinal plant Cleistochlamys kirkii from Tanzania yielded 13 new metabolites including two chlorinated cyclohexenes, cleistenechlorohydrins A (143) and B (144) (Figure 29). ${ }^{70}$ This plant is a member of the genus of the family Annonaceae and is native to several eastern and southern African countries. For example, in Mozambique this plant is used to treat wound infections, rheumatism, and tuberculosis. ${ }^{71}$<smiles>CC(=O)OC[C@@H](O)[C@H](Cl)/C=C(/CCOC(C)(C)C)COC(C)(C)C</smiles>

141 (albanol A)

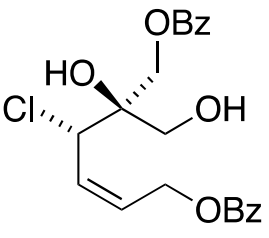

142 (albanol B)<smiles>CC(=O)OC[C@]1(O)[C@@H](Cl)C=C[C@@H](OC(C)=O)[C@@H]1O</smiles>

143 (cleistenechlorohydrin A)<smiles>CC(=O)OC1[C@H](Cl)C=C[C@@H](OC(C)=O)[C@]1(O)COC(C)(C)C</smiles>

144 (cleistenechlorohydrin B)

Figure 29. Structures of new chlorinated metabolites from terrestrial plants.

Chinese agarwood (Aquilaria sinensis Lour.) Gilg. (Thymelaeaceae) is the source of three new chlorinated 2-(2-phenylethyl)chromones, 145 - 147, in addition to two non-chlorinated analogues and 11 known compounds. ${ }^{72}$ The absolute configurations were determined and these compounds exhibit strong inhibition of nitric oxide production in RAW 264.7 cells $\left(\mathrm{IC}_{50}=3.8-7.3 \mu \mathrm{M}\right)$. A collection of Seidlitzia rosmarinus from the Sinai desert shoreline of the Gulf of Aqaba, Egypt, yielded the novel, isomeric $\alpha$-chloroferuloylamides 148 and 149 (Figure 30). ${ }^{73}$<smiles>COc1ccc(CCc2cc(=O)c3c(o2)[C@H](Cl)[C@H](O)[C@@H](O)[C@H]3O)cc1</smiles>

145<smiles></smiles>

146<smiles>COc1ccc(CCc2cc(=O)c3c(o2)[C@H](Cl)[C@H](O)[C@H](O)[C@H]3O)cc1</smiles>

147<smiles>COc1cc(/C=C(\Cl)C(=O)NCCc2ccc(O)cc2)ccc1O</smiles>

148 (2-chloro-N-Z-feruloyltyramine)<smiles>COc1cc(/C=C(/Cl)C(=O)NCCc2ccc(O)cc2)ccc1O</smiles>

149 (2-chloro-N-E-feruloyltyramine)

Figure 30. Structures of new chlorinated metabolites from terrestrial plants. 
The traditional Chinese medicine plant Curculigo orchioides ("Xianmao") collected from Yunnan Province,

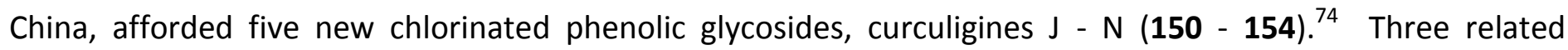
glycosides were isolated from Przewalskia tangutica (Solanaceae), przewatangosides A - C (155 - 157), a plant found in the Tibet region of China (Figure 31). ${ }^{75}$ Only 155 shows (weak) activity against SMMC-7721 (liver carcinoma) $\left(\mathrm{IC}_{50}=38.1 \mu \mathrm{M}\right)$.<smiles>Cc1cc(O)c(Cl)c(OC2OC(CO)C(O)C(O)C2O)c1</smiles>

150 (curculigine J)

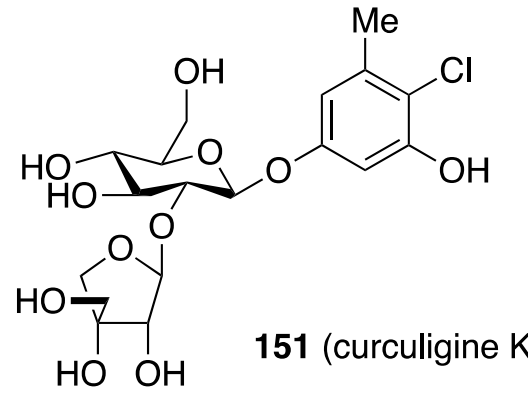<smiles>Cc1cc(OC2OC3COC(OC(CO)C(O)C3O)C(O)C(O)C(O)C2O)cc(O)c1Cl</smiles>

152 (curculigine L)

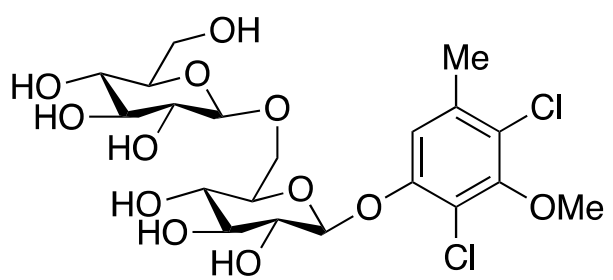

153 (curculigine M)

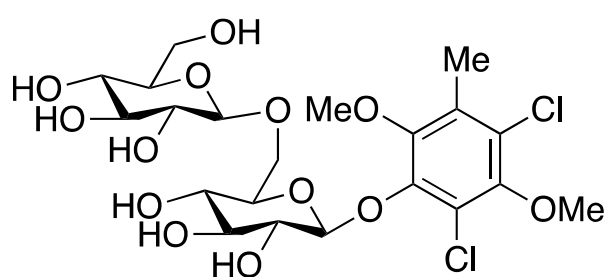

154 (curculigine $\mathrm{N}$ )<smiles>C/C=C/c1cc(O)c(Cl)c(OC)c1OC1OC(CO)C(O)C(O)C1O</smiles>

155 (przewatangoside A)<smiles>C/C=C/c1c(Cl)c(O)c(Cl)c(OC)c1OC1OC(CO)C(O)C(O)C1O</smiles>

156 (przewatangoside B)<smiles>C/C=C/c1c(Cl)c(OC)c(Cl)c(OC)c1OC1OC(CO)C(O)C(O)C1O</smiles>

157 (przewatangoside C)

Figure 31. Structures of new chlorinated phenolic glycosides from terrestrial plants.

The Chinese herb Valeriana jatamansi (Caprifoliaceae), which is an important traditional Chinese medicine for the treatment of nervous disorders, epilepsy, insanity, snake poisoning, and skin diseases, ${ }^{76}$ furnished three new chlorinated iridoids, chlorovaltrates $P$ - R (158 - 160), in addition to five previously known chlorinated iridoids. ${ }^{77}$ A collection of Phlomis likiangensis (Lamiaceae) from Yunnan, China, yielded six new

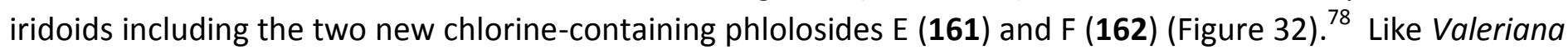
jatamansi (vide supra), the Phlomis genus is used as a herbal tea to cope with gastrointestinal diseases and other disorders. $^{78}$ Chlorine-containing iridoids are probably the largest collection of organochlorines present in the terrestrial environment. ${ }^{2,3}$ 
<smiles>C=C1C2CC3(CCl)C(O)C1OC3C2OC</smiles>

158 (chlorovaltrate P)<smiles>COC1OCC(=O)C2(O)C[C@H](O)[C@@H](CCl)[C@H]12</smiles>

159 (chlorovaltrate Q)<smiles>C=C1COC(OC)C2C1CC(O)C2CCl</smiles>

160 (chlorovaltrate $\mathrm{R}$ )

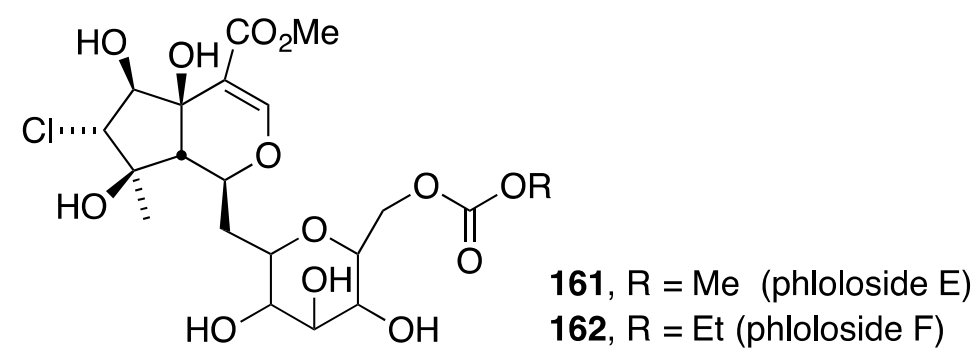

Figure 32. Structures of new chlorinated iridoids terrestrial plants.

Another traditional Chinese medicine plant for pain relief dating back to the $1^{\text {st }}$ century is Rhododendion molle G.Don. A gathering of the fruits of this plant from Guangxi Province, China, led to the discovery of three new chlorinated diterpenoids rhodomollein XXXI - XXXIII (163 - 165) in a group of 12 new compounds isolated in this study (Figure 33). ${ }^{79}$ All three metabolites show significant antinociceptive activity, especially 164 and 165 at a very low dose $(2 \mathrm{mg} / \mathrm{kg})$.

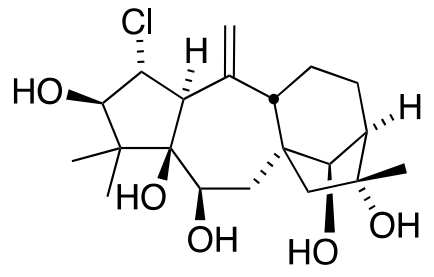

163 (rhodomollein XXXI)

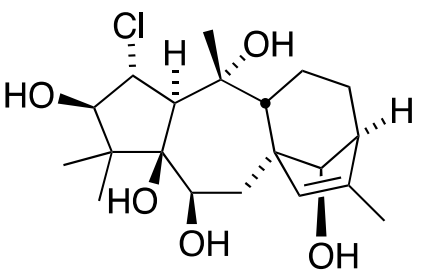

164 (rhodomollein XXXII)

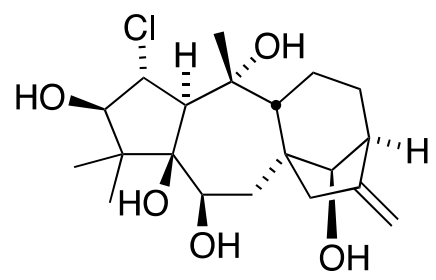

165 (rhodomollein XXXIII)

Figure 33. Structures of new chlorinated diterpenoids from Rhododendion molle G.Don.

In contrast to chlorinated terpenoids (vide supra), chlorinated plant alkaloids are exceedingly rare. ${ }^{2,3,5}$ Two examples were identified in 2017. The plant Ficus fistulosa var. tengerensis (Moraceae) from Malaysia contains the novel tengechlorenine (166) as a pair of phenanthroindolizidine enantiomers. ${ }^{80}$ This alkaloid shows strong cytotoxicity against three breast cancer cell lines, MDA-MB-468, MDA-MB-231, and MCF-7 (IC 50 $=0.038-0.91 \mu \mathrm{M}$ ). The widely distributed plant Rauvolfia vomitoria (Apocynaceae) contains the unusual alkaloid rauvomine $\mathrm{A}(\mathbf{1 6 7 )}) .^{81}$ This plant is found in the tropical regions of Africa and Asia, and has been used to treat fever, gastrointestinal and liver diseases, pain, and some cancers. 
<smiles>COc1cc2c3c(c4ccc(OC)c(Cl)c4c2cc1OC)CN1CCCC1C3</smiles>

166 (tengechlorenine)

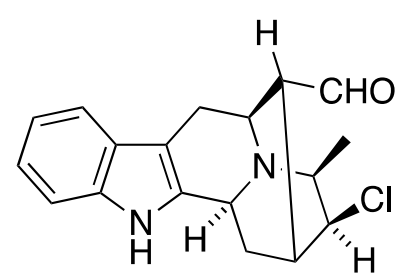

167 (rauvomine A)

Figure 34. Structures of new chlorinated alkaloids from terrestrial plants.

\subsection{Terrestrial fungi}

Terrestrial fungi are prodigious fabricators of natural products, many of which contain halogen. New examples are discovered yearly. ${ }^{2,3}$

The genus Colletotrichum includes a large group of fungal plant pathogens that cause disease to many crops, and this fungus is extremely detrimental to agriculture. ${ }^{82}$ An examination of the fungus Colletotrichum higginsianum afforded the novel colletochlorins $G$ (168) and $H$ (169) along with five known related metabolites. ${ }^{83}$ The absolute configuration of the colletochlorins could not be determined. Five new and five known metabolites were isolated from the ubiquitous fungus Aspergillus unguis that includes the novel aspergillusethers $C(\mathbf{1 7 0})$ and $D(\mathbf{1 7 1})$ (Figure 35). ${ }^{84}$ This fungal sample was collected from Surat Thani province in Thailand. The dichlorinated $\mathbf{1 7 1}$ is 4 to 8 times more active than the monochlorinated 170 in antifungal activity towards Candida albicans, Cryptococcus neoformans, and Penicillium marnefeii (MIC = 16, 8 , $16 \mu \mathrm{g} / \mathrm{mL}$, respectively).<smiles>Cc1cc(O)c2c(c1Cl)OC(C)(C)C(O)C2</smiles>

168 (colletochlorin $\mathrm{G}$ )<smiles>C/C=C(\C)c1cc(O)c(C)c(O)c1Oc1cc(O)c(Cl)c(C)c1C(C)=O</smiles>

170 (aspergillusether C)<smiles>Cc1cc(O)c2c(c1Cl)C(C)(C)OC(O)C2</smiles>

169 (colletochlorin $\mathrm{H}$ )<smiles>C/C=C(\C)c1c(Cl)c(O)c([N+](C)=O)c(O)c1Oc1cc(O)c(Cl)c(C)c1C(C)=O</smiles>

171 (aspergillusether D)

Figure 35. Structures of new chlorinated metabolites from terrestrial fungi.

Fermentation broths of Penicillium concentricum, an endophytic fungus of the Liverwort Trichocolea tomentella (Trichocoleaceae), produced an array (more than 20) of metabolites including the novel 172 175. ${ }^{85}$ Metabolites 172 and $\mathbf{1 7 3 / 1 7 4}$ are cytotoxic to MCF-7 breast cancer cells $\left(\mathrm{IC}_{50}=8.4\right.$ and $9.7 \mu \mathrm{M}$, 
respectively). This liverwort was collected in Newport, Virginia. The mangrove Bruguiera sexangula var. rhynchopetala from the South China Sea is host to the fungus Penicillium citrinum HL-5126, and the latter produces the chlorinated xanthone 176 and anthraquinone 177 (Figure 36). ${ }^{86}$ Metabolite 177 is antibacterial against Vibrio parahaemolyticus (MIC $=10 \mu \mathrm{M}$ ).<smiles>Cc1cc(O)cc2oc3cc(Cl)cc(O)c3c(=O)c12</smiles>

172 (6-chloro-3,8-dihydroxy-1-methylxanthone)<smiles>O=C1C(CO)=C[C@@H](O)[C@H](O)[C@@H]1Br</smiles>

174 (6-dehydroxy-6 $\alpha$-bromogabosine C)<smiles>OCc1cc(O)cc(Br)c1O</smiles>

173 (2-bromogentisyl alcohol)<smiles>O=C1C(CO)=C[C@@H](O)[C@H](O)[C@H]1Br</smiles>

175 (6-dehydroxy-6 $\beta$-bromogabosine C)<smiles>COc1cc(O)c2c(=O)c3c(Cl)cc(C)cc3oc2c1Cl</smiles>

176 (4-chloro-1-hydroxy-3-methoxy-6-methyl-8-methoxycarbonyl-xanthen-9-one)<smiles>COc1c(Cl)c(O)cc2c1C(=O)c1c(O)cc(COC(C)=O)cc1C2=O</smiles>

177 (2'-acetoxy-7-chlorocitreorosein)

Figure 36. Structures of new halogenated metabolites from terrestrial Penicillium sp. fungi.

The fungal pathogen Cochliobolus australiensis was isolated from infected leaves of the invasive weed "buffel grass" Pennisetum ciliare (syn. Cenchrus ciliaris), which is a major problem in southern Arizona. From this pathogen were isolated the new metabolites chloromonilinic acids $C(\mathbf{1 7 8})$ and $D(\mathbf{1 7 9})$, in addition to some previously known metabolites. ${ }^{87}$ The stem bark of the Chinese tree Melia azedarach Linn. from Jiangsu Province, China, is associated with the fungus Pestalotiopsis sp. Extraction of this fungus led to the novel pestalachloride $G(\mathbf{1 8 0})$ as a racemate. ${ }^{88}$ It shows strong antimicrobial activity against several pathogenic bacteria (Escherichia coli, Pseudomonas aeruginosa, Staphylococcus aureus, and Bacillus subtilis; $\mathrm{MIC}_{50}=4.1$, $15.0,13.5,16.5 \mu \mathrm{g} / \mathrm{mL}$, respectively). Both enantiomers of 180 show similar bioactivities. Cultures of the fungus Helminthosporium velutinum yone96, which was isolated from dead twigs of a woody plant from Yakushima Island, Japan, led to cyclohelminthol X (181). ${ }^{89}$ This complex metabolite shows activity against 
COLO 201 (colon) and (especially) HL-60 (leukemia) cells ( $\mathrm{IC}_{50}=16$ and $0.35 \mu \mathrm{M}$, respectively), and displays proteasome inhibition. Some fungal metabolites are structurally simple, such as 8-chloroxylarinol A (182) isolated from Malbranchea flavorosea (Figure 37). ${ }^{90}$ Metabolite 182 is a strong inhibitor of $\alpha$-glucosidase. The genus Malbranchea (Myxotrichaceae) is a worldwide soil-based fungus.<smiles>COC(=O)C=C(Cl)c1oc2cc(C)cc(O)c2c(=O)c1[C@H](O)C(=O)O</smiles>

178 (chloromonilinic acid C)<smiles>CC(=O)Cc1c(/C(Cl)=C/C(=O)O)oc2cc(C)cc(O)c2c1=O</smiles>

179 (chloromonilinic acid D)<smiles>C=C(C)[C@H]1Cc2c(O)cc(O)c(C=O)c2[C@@]1(O)c1c(O)c(Cl)c(C)c(Cl)c1OC</smiles>

180 (pestalachloride $\mathrm{G}$ )

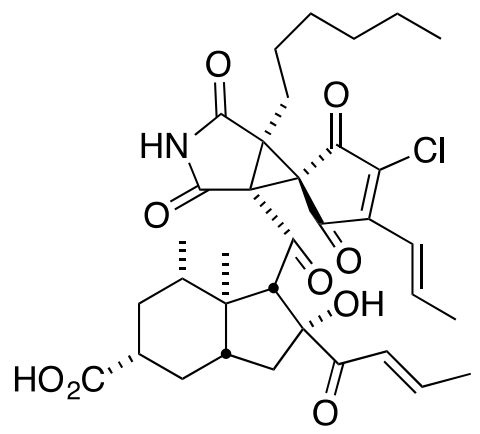<smiles>O=C1C=Cc2ccc(Cl)c(O)c2CO1</smiles>

182 (8-chloroxylarinol A)

181 (cyclohelminthol X)

Figure 37. Structures of new chlorinated metabolites from terrestrial fungi.

A classic antifungal agent is griseofulvin and a new derivative of it was isolated from Penicilium griseofulvum CPCC 400528, 4'-demethoxy-4'-N-isopentylisogriseofulvin (183), along with several other metabolites including griseofulvin. ${ }^{91}$ This new metabolite is active against $\mathrm{HIV}\left(\mathrm{IC}_{50}=33.2 \mu \mathrm{M}\right)$. The mangrove plant Sonneratia caseolaris in Hainan Province, China, is associated with the endophytic fungus Penicillium janthinellum HDN13-309 and the latter yielded a series of alkaloids, including the chlorine-containing penicisulfuranols $A(\mathbf{1 8 4})$ and D (185) along with four non-chlorinated analogues (Figure 38). ${ }^{92}$ Metabolite 184 shows potent cytotoxicity towards $\mathrm{HeLa}$ and $\mathrm{HL}-60$ cells $\left(\mathrm{IC}_{50}=0.5\right.$ and $0.1 \mu \mathrm{M}$, respectively). These novel compounds possess a rare 1,2-oxazadecaline core and the unusual spiro-furan ring.

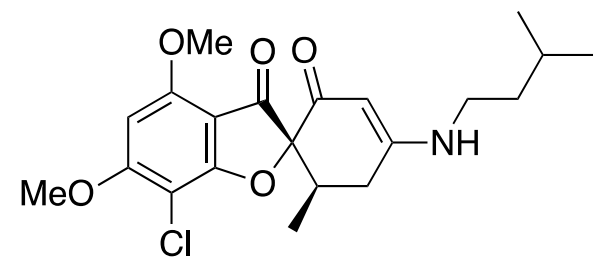

183 (4'-demethoxy-4'- $N$-isopentylisogriseofulvin)

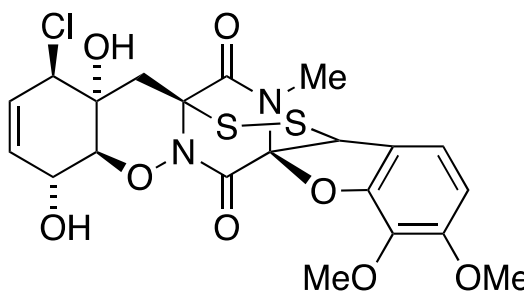

184 (penicisulfuranol A)<smiles>COc1ccc2c(c1OC)O[C@@]1(C(=O)N3O[C@@H]4[C@@H](O)C=C[C@H](Cl)[C@]4(O)C[C@]3(SC)C(=O)N1C)[C@H]2C</smiles>

185 (penicisulfuranol D)

Figure 38. Structures of new chlorinated metabolites from terrestrial Penicilium fungi. 
The legume-infesting fungus Diaporthe toxica causes fatal liver disease in lupin-fed sheep. The major responsible toxin is phomopsin $A$. The present study discovered a new metabolite of this fungus, phomopsin $F$ (186), the $N$-methylated derivative of phomopsin $A{ }^{93}$ The new dichlorinated dehydrocurvularin 187 was characterized from Alternaria sp. AST0039, which is a fungal endophyte of Astragalus lentiginosus (Fabaceae, "spotted locoweed"), collected in central Arizona. ${ }^{94}$ The chlorinated lepistatins A - C (188 - 190) were isolated from the culture broth of the basidiomycete Lepista sordida (Figure 39). ${ }^{95}$ No significant antibacterial and antiproliferative activities of these lepistatins are observed at $25 \mu \mathrm{g} / \mathrm{mL}$.

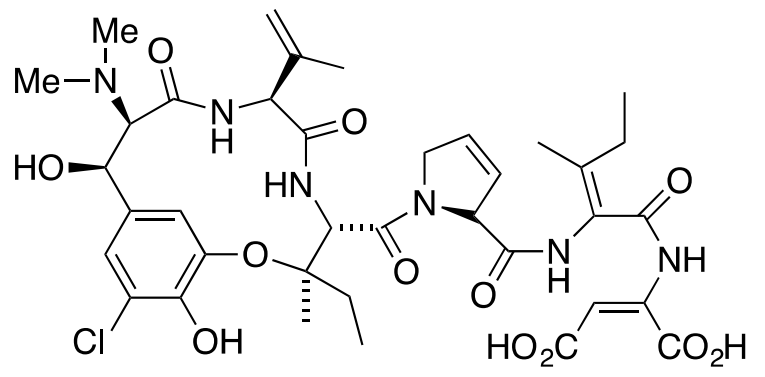<smiles>CO[C@H](C)CC/C=C/C(=O)c1c(O)c(Cl)c(O)c(Cl)c1CC(=O)O</smiles>

186 (phomopsin F)

$187((-)(10 E, 15 S)$-4,6-dichloro-10(11)-dehydrocurvularin)<smiles>C=C(CO)c1c(O)c(Cl)c(C)c2c1CC(C)(C)C2=O</smiles>

188 (lepistatin A)<smiles>C=C(CO)c1c(O)c(Cl)c(C)c2c1C[C@](C)(CO)C2=O</smiles>

189 (lepistatin B)<smiles>Cc1c(Cl)c(O)c(C(CO)CO)c2c1C(=O)C(C)(C)C2</smiles>

190 (lepistatin C)

Figure 39. Structures of new chlorinated metabolites from terrestrial fungi.

Botrysphaeria laricina is a fungus associated with the moss Rhodobryum umgiganteum living in Yunnan Province, China. This fungus produces the new chlorinated cyclohexenones botrysphones A (191) and C (192), along with a suite of other metabolies, including the known chlorosphaeropsidone. ${ }^{96}$ The novel cosmochlorins $D(193)$ and $E(194)$ were characterized from endophytes associated with the shrub Ficus ampelas (Moraceae) (Figure 40). The producing organism is Phomopsis sp. N-125. ${ }^{97}$ Both 193 and 194 are cytotoxic towards HL-60 cells $\left(\mathrm{IC}_{50}=6.1\right.$ and $1.8 \mu \mathrm{M}$, respectively).<smiles>O=C1C=C(O)[C@@H](Cl)[C@H](O)[C@H]1O</smiles>

191, $R=$ Me (botrysphone $A)$ 192, $R=$ Et (botrysphone $C$ )<smiles>COc1cc(OC)c(Cl)c(/C(C)=C/C(C)=O)c1Cl</smiles>

193 (cosmochlorin D)<smiles>COc1cc(OC)c(Cl)c(/C(C)=C/C(C)=C/C(C)=O)c1Cl</smiles>

194 (cosmochlorin E)

Figure 40. Structures of new chlorinated metabolites from terrestrial fungi. 


\subsection{Terrestrial bacteria}

No other organism produces metabolites more complex than those produced by terrestrial bacteria. Some of these natural products are life-saving antibiotics, like the glycopeptide vancomycin.

An examination of Actinoallomurus sp. ID145698 revealed the presence of new angucyclinones, the allocyclinones A-D (195-198). ${ }^{98}$ These metabolites are active towards Gram positive bacteria with MIC values of $0.25-1 \mu \mathrm{g} / \mathrm{mL}$, with the exception of Enterococcus faecium. The activity increases with the increasing number of chlorines (195 > $198>197>196)$. A soil-derived Actinomadura strain produces the novel polyether polyketide nonthmicin (199) (absolute configuration shown), which shows potent antimicrobial activity $\left(I_{50}=\right.$ $0.0013-0.005 \mu \mathrm{g} / \mathrm{mL}$ ) against Kocuria rhizophia, Bacillus cereus, Staphylococcus aureus, and Enterococcus faecalis (Figure 41). ${ }^{99}$ Interestingly, the dechlorinated ecteinamycin metabolite is much less active against all four organisms $(\mathrm{MIC}=0.01 \mu \mathrm{g} / \mathrm{mL})$.

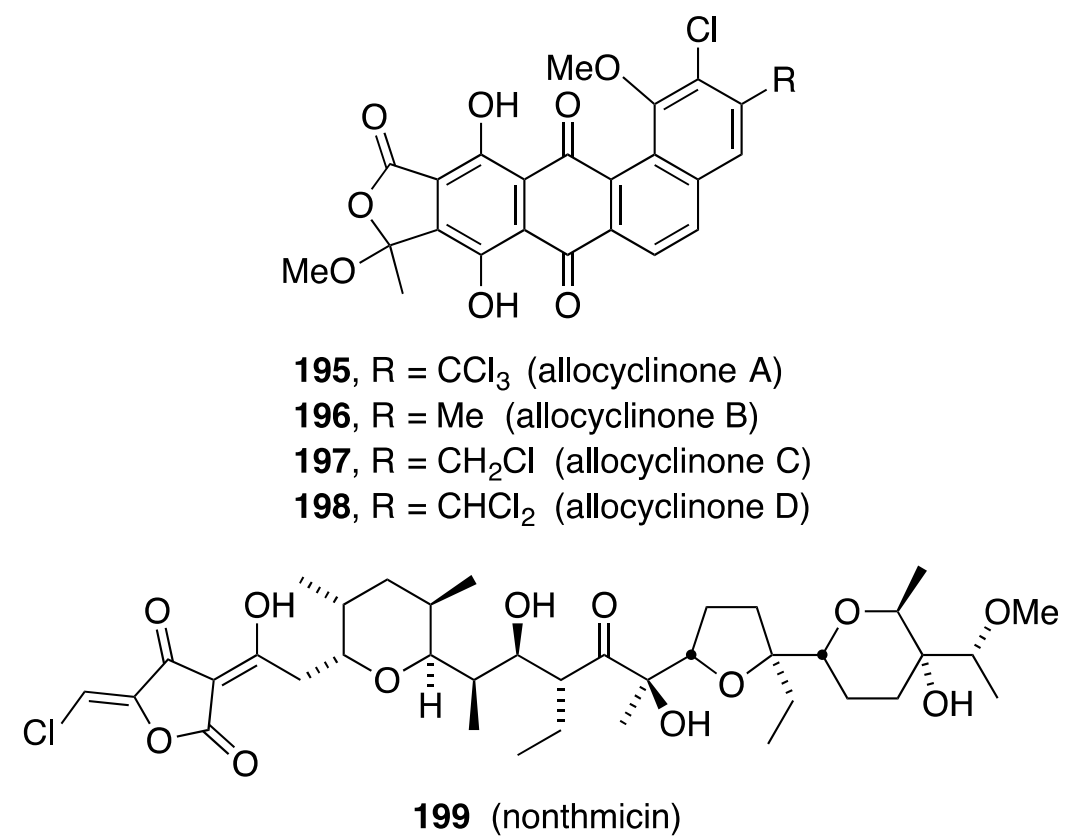

Figure 41. Structures of new chlorinated metabolites from terrestrial bacteria.

The rare Microbacterium sp. was isolated from the gut of the carrion beetle (Nicrophorus concolor) and found to produce the novel chlorinated cyclic peptides nicrophorusamides A (200) and B (201). ${ }^{100}$ The former metabolite $\mathbf{2 0 0}$ is eight times more active than 201 against several pathogenic bacterial strains (Staphylococcus aureus, Enterococcus faecalis, Enterococcus faecium, and Salmonella enterica) (MIC = 8-16 $\mu \mathrm{g} / \mathrm{mL}$ ), but both 200 and 201 are inactive towards several pathogenic fungi and display no cytotoxicity against various human cancer cell lines. The strain Streptomyces sp. KCB13F003 has led to two ulleungmycins A (202) and B (203), ${ }^{101}$ which are very similar to the microphorusamides 200 and 201 (Figure 42). 


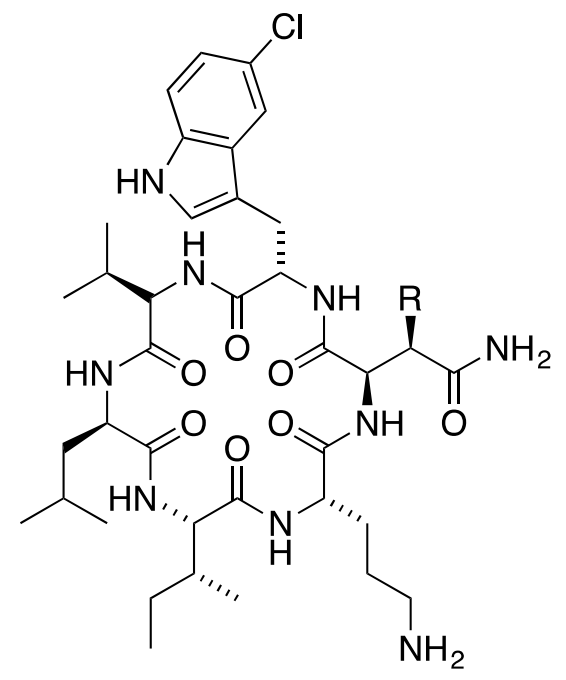

200, $\mathrm{R}=\mathrm{OH}$ (microphorusamide $A)$

201, $\mathrm{R}=\mathrm{H}$ (microphorusamide $B$ )

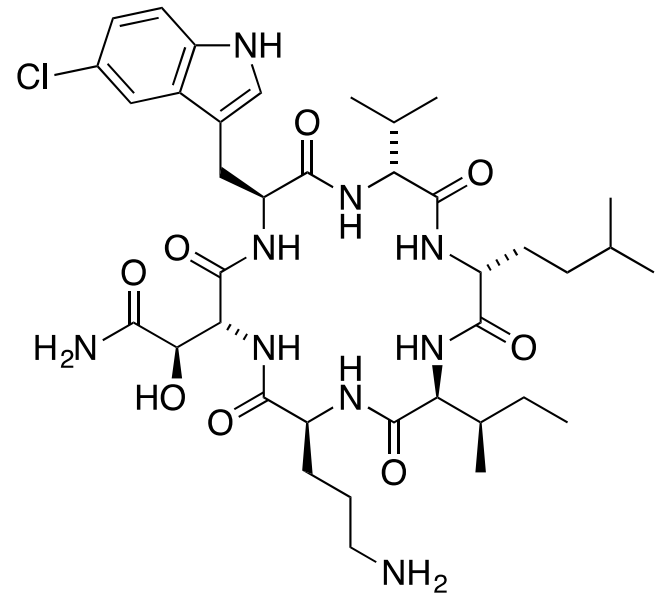

202 (ulleungmycin A)<smiles>CCC(C)[C@H](NC(=O)[C@H](CC(C)C)NC(=O)[C@H](NC(=O)[C@H](CCCN)NC(=O)[C@H](NC(=O)[C@H](Cc1c[nH]c2ccc(Cl)cc12)C(C)C)C(=O)N[C@@H](CCCN)C(N)=O)C(N)=O)C(C)C</smiles>

203 (ulleungmycin B)

Figure 42. Structures of new chlorinated cyclic peptides from terrestrial bacteria.

Another Streptomyces sp. (DSM14386) afforded seven new halogenated peptides, the svetamycins A - G (204 - 210) (Figure 43). ${ }^{102}$ Svetamycin $G(\mathbf{2 1 0})$ is the most active of these metabolites against the growth of Mycobacterium smegmatis ( $\mathrm{MIC}_{80}=2 \mu \mathrm{g} / \mathrm{mL}$ ). Svetamycins $\mathrm{A}(\mathbf{2 0 4})$ and $\mathrm{C}(206)$ are cytotoxic towards HepG2 (hepatoma), $\mathrm{IC}_{50}=11.0$ and $3.6 \mathrm{\mu g} / \mathrm{mL}$, respectively. A study of the several microsclerodermins from terrestrial myxobacteria uncovered the new microsclerodermin $L$ (211). 


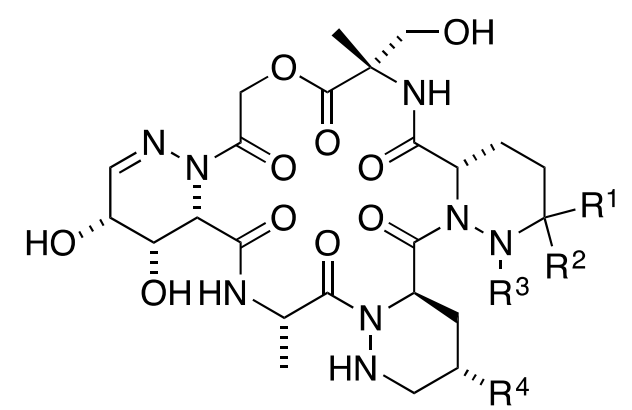

204, $R^{1}=R^{2}=R^{3}=H, R^{4}=C l$ (svetamycin A)

205, $R^{1}=R^{3}=H, R^{2}=M e, R^{4}=C l$ (svetamycin $B$ )

206, $R^{1}=R^{2}=M e, R^{3}=H, R^{4}=C l$ (svetamycin C)

207, $R^{1}=H, R^{2}=R^{3}=\pi$ bond, $R^{4}=C l$ (svetamycin $D$ )

209, $R^{1}=R^{2}=R^{3}=H, R^{4}=B r$ (svetamycin $F$ )

210, $R^{1}=R^{2}=M e, R^{3}=H, R^{4}=B r$ (svetamycin $G$ )<smiles>C[C@H](NC(=O)[C@@H]1[C@H](O)[C@@H](O)C=NN1C(=O)CO)C(=O)N1NC[C@@H](Cl)C[C@H]1C(=O)N1NC(C)(C)CC[C@H]1C(=O)N[C@@](C)(CO)C(=O)O</smiles>

208 (svetamycin E)

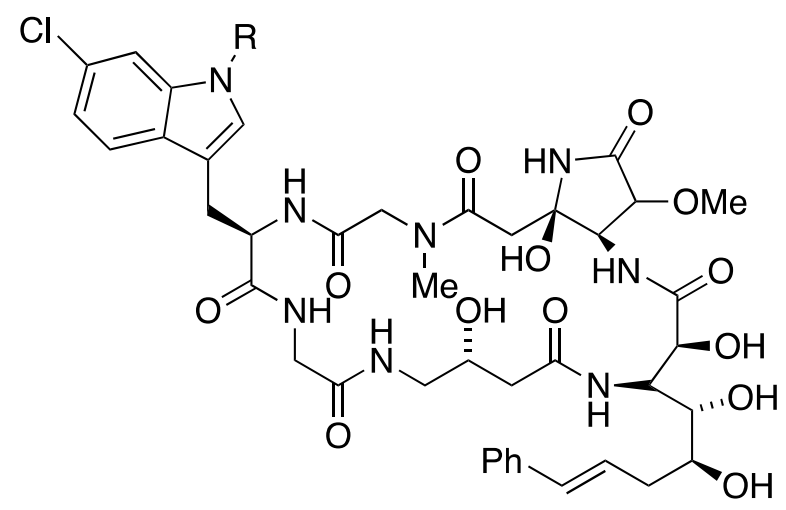

211 (microsclerodermin L)

Figure 43. Structures of new chlorinated cyclic peptides from terrestrial bacteria.

\subsection{Slime mold}

Once classified as a fungus, slime mold (slime mould) is the name given to several unrelated organisms that either live freely as single cells or as unified structures. Some 900 species are known worldwide.

The bacteria-eating slime mold Dictyostelium monochasioides produces eight chlorinated alkylresorcinols, monochasiols A-H (212-219), the structures of which were confirmed by synthesis (Figure 44). ${ }^{104}$ Monochasiol A (212) inhibits the concanavalin A-induced interleukin-2 production in Jurkat cells, which is a human T lymphocyte cell line. 
13
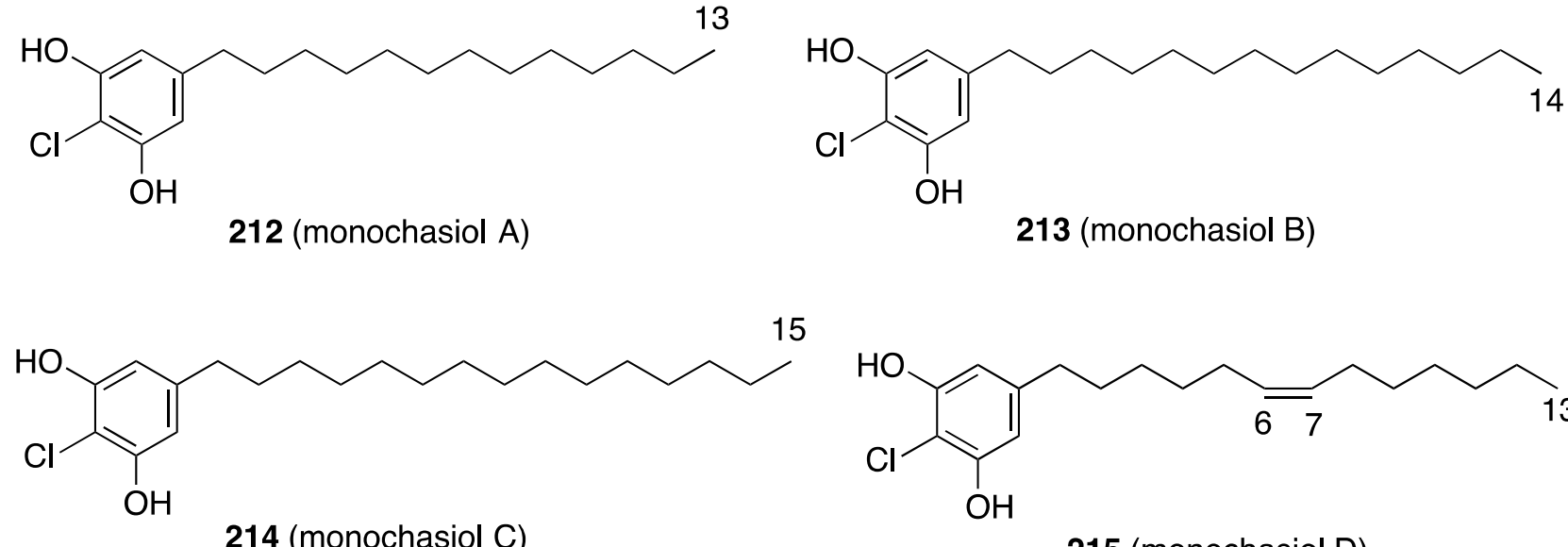

15

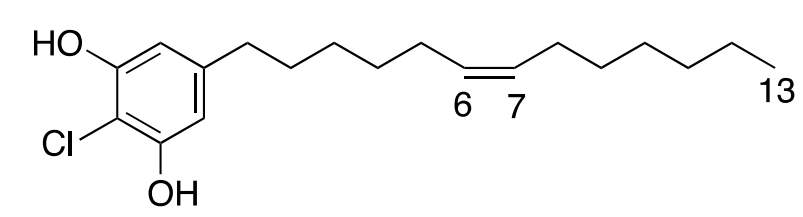

215 (monochasiol D)

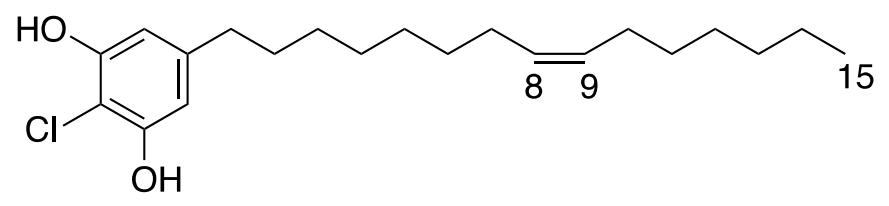

216 (monochasiol E)<smiles>Oc1cc(CCCCCCC[C@@H]2C[C@H]2CCCCC[13S])cc(O)c1Cl</smiles>

218 (monochasiol G)

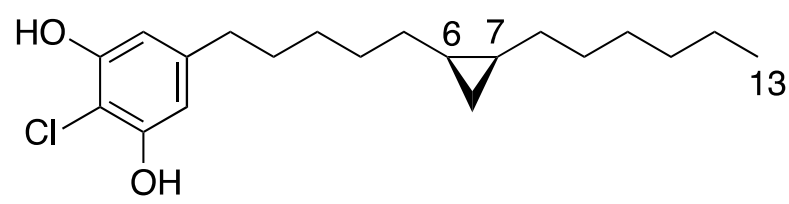

217 (monochasiol F)

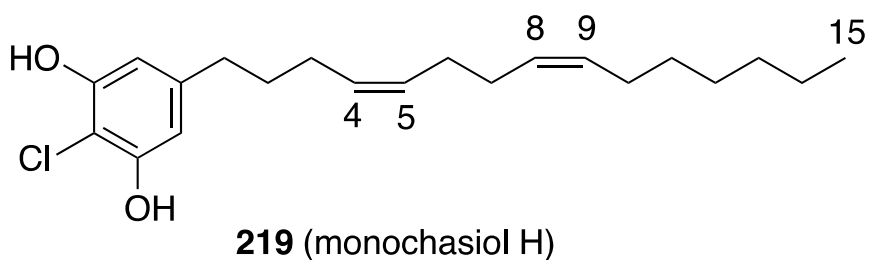

Figure 44. Structures of new chlorinated alkylresorcinols from Dictyostelium monochasioides.

\subsection{Miscellaneous}

Two other new, and quite surprising, natural sources of organohalogens were described in 2017.

As do termites, ${ }^{105}$ red wood ants produce $\mathrm{CH}_{3} \mathrm{Cl}, \mathrm{CHCl}_{3}, \mathrm{CCl}_{4}$, and $\mathrm{CHBr}_{3}{ }^{106}$ For example, the average concentrations in the nests of Formica rufa and Formica polyctena are up to three-fold higher than the atmospheric background and as much as 70-fold higher than volcanic emissions, which are generally considered as one of the main geogenic sources of $\mathrm{CHCl}_{3}$. Bromoform was up to 20-fold higher than atmospheric background.

An astounding finding was the interstellar detection of $\mathrm{CH}_{3} \mathrm{Cl}$ and $\mathrm{CH}_{3} \mathrm{~F}$ in the gas surrounding the protostar IRAS 16293-2422, and the presence of $\mathrm{CH}_{3} \mathrm{Cl}$ in the coma of the comet 67P/ChuryumovGerasimenko. ${ }^{107}$ The authors of this discovery calculate that approximately 600 tons/year of $\mathrm{CH}_{3} \mathrm{Cl}$ could have been delivered to the young earth based on the cometary $\mathrm{CH}_{3} \mathrm{Cl}$ abundance and during the heavy bombardment over 80 million years. This amounts to 50 gigatons of $\mathrm{CH}_{3} \mathrm{Cl}$.

Halocarbon emissions from marine phytoplankton as influenced by climate change was reviewed in 2017. ${ }^{108,109}$ Some 40 low-molecular weight organohalogens were evaluated in these studies. Also evaluated were the formations of haloacetic acids and trihalomethanes that are produced by peracetic acid and chlorine drinking water disinfection processes. ${ }^{110}$ No new organohalogens were described in either of these three investigations. 


\section{Conclusions}

Contrary to the widespead belief - pervasive prior to 1980 - that "nature would never make halogencontaining natural products," the past several decades have shown that literally thousands of organohalogen natural products have now been identified, ${ }^{2,3}$ approximating 6,000! As we have seen in this brief review, the frequency of the discovery of new naturally occurring organohalogen compounds - 100-200 per year - has sustained for the year 2017. Marine and terrestrial organisms alike continue to amaze with their inexorable output of novel halogen-containing compounds. Given the fact that of the 500,000 estimated marine organisms $^{111}$ - which are the source of most organohalogens - only a small percentage have been investigated for their chemical content, it is certain that myriad new natural organohalogens are awaiting discovery. Of the estimated 1.5 million species of fungi, secondary metabolites have been characterized from only 5,000 species. ${ }^{112}$ The future is bright for the collector of naturally occurring organohalogens!

This increased activity in natural products research, of all types, may be attributed to modern collection methods (e.g., SCUBA and remote submersibles for the collection of previously inaccessible marine organisms), selective bioassay for identifying biologically active compounds, powerful multidimensional NMR and mass spectral techniques for characterizing sub-milligram amounts of compounds, and new separation and purification techniques (e.g., counter-current chromatography and HPLC). All of this ensures that even the most structurally intricate natural products can be identified. Finally, knowledge and appreciation of folk medicine and ethobotany will continue to guide chemists to new biologically active natural products, including organohalogen compounds.

But what is the raison d'être for the existence of natural organohalogens? This is the big question! Some organohalogens function as pheromones and hormones, as antifeedants and antifoulants, as natural pesticides, as recyclers of halogen, and as structural proteins. Many organohalogen compounds display enormous biological activity that may lead to clinical drugs of benefit to mankind.

\section{Acknowledgements}

The author is indebted to Wendy Berryman for typing this manuscript and drawing the chemical structures.

\section{References}

1. Fowden, L. Proc. Roy. Soc. B 1968, 171, 5. https://doi.org/10.1098/rspb.1968.0052

2. Gribble, G. W. Prog. Chem. Org. Nat. Prod. 1996, 68, 1.

3. Gribble, G. W. Prog. Chem. Or. Nat. Prod. 2010, 91, 1.

4. Gribble, G. W. Environ. Chem. 2015, 12, 396.

https://doi.org/10.1071/EN15002

5. Gribble, G. W. The Alkaloids 2012, 71, 1.

6. Gribble, G. W. Mar. Drugs 2015, 13, 4044.

https://doi.org/10.3390/md13074044

7. Gribble, G. W. Heterocycles 2012, 84, 157.

https://doi.org/10.3987/REV-11-SR(P)5

8. Wang, L.; Zhou, X.; Fredimoses, M.; Liao, S.; Liu, Y. RSC Adv. 2014, 4, 57350.

https://doi.org/10.1039/C4RA09833A 
9. Blunt, J. W.; Carroll, A. R.; Copp, B. R.; Davis, R. A.; Keyzers, R. A.; Prinsep, M. R. Nat. Prod. Rep. 2018, 35, 8. https://doi.org/10.1039/C7NP00052A

10. Bawakid, N. O.; Alarif, W. M.; Ismail, A. I.; El-Hefnawy, M. E.; Al-Footy, K. O.; Al-Lihaibi, S. S. Phytochemistry 2017, 143, 180. https://doi.org/10.1016/i.phytochem.2017.08.001

11. Morales-Amador, A.; de Vera, C. R.; Márquez-Fernández, O.; Daranas, A. H.; Padrón, J. M.; Fernández, J. J.; Souto, M. L.; Norte, M. Mar. Drugs 2018, 16, 5. https://doi.org/10.3390/md16010005

12. Yu, X.-Q.; Jiang, C.-S.; Zhang, Y.; Sun, P.; Kurtán, T.; Mándi, A.; Li, X.-L.; Yao, L.-G.; Liu, A.-H.; Wang, B.; Guo, Y.-W.; Mao, S.-C. Phytochemistry 2017, 136, 81.

https://doi.org/10.1016/i.phytochem.2017.01.007

13. Oguri, Y.; Watanabe, M.; Ishikawa, T.; Kamada, T.; Vairappan, C. S.; Matsuura, H.; Kaneko, K.; Ishii, T.; Suzuki, M.; Yoshimura, E.; Nogata, Y.; Okino, T. Mar. Drugs 2017, 15, 267. https://doi.org/10.3390/md15090267

14. Xu, X.; Yang, H.; Khalil, Z. G.; Yin, L.; Xiao, X.; Neupane, P.; Bernhardt, P. V.; Salim, A. A.; Song, F.; Capon, R. J. Mar. Drugs 2017, 15, 374. https://doi.org/10.3390/md15120374

15. Islam, M. R.; Mikami, D.; Kurihara, H. Tetrahedron Lett. 2017, 58, 4119. https://doi.org/10.1016/j.tetlet.2017.09.044

16. Lavoie, S.; Brumley, D.; Alexander, T. S.; Jasmin, C.; Carranza, F. A.; Nelson, K.; Quave, C. L.; Kubanek, J. J. Org. Chem. 2017, 82, 4160.

https://doi.org/10.1021/acs.joc.7b00096

17. Gallardo, A. B.; Cueto, M.; Díaz-Marrero, A. R.; de la Rosa, J. M.; Fajardo, V.; San-Martín, A.; Darias, J. Phytochemisstry 2018, 145, 111.

https://doi.org/10.1016/i.phytochem.2017.06.010

18. Mithoo-Singh, P. K.; Keng, F. S.-L.; Phang, S.-M.; Elvidge, E. C. L.; Sturges, W. T.; Malin, G.; Rahman, N. A. PeerJ 2017, DOI 10.7717/peerj.2918.

https://doi.org/10.7717/peerj.2918

19. Qi, S.-H.; Ma, X. Mar. Drugs 2017, 15, 263. https://doi.org/10.3390/md15090263

20. Wang, K.-L.; Wu, Z.-H.; Wang, Y.; Wang, C.-.; Xu, Y. Mar. Drugs 2017, 15, 266. https://doi.org/10.3390/md15090266

21. Chen, L.; Qian, P.-Y. Mar. Drugs 2017, 15, 264. https://doi.org/10.3390/md15090266https://doi.org/10.3390/md15090264

22. Zhang, H.; Dong, M.; Chen, J.; Wang, H.; Tenney, K.; Crews, P. Mar. Drugs 2017, 15, 351. https://doi.org/10.3390/md15110351

23. Molinski, T. F. Org. Biomol. Chem. 2018, 16, 21. https://doi.org/10.1039/C7OB02628E

24. Sun, J.; Wu, J.; An, B.; de Voogd, N. J.; Cheng, W.; Lin, W. Mar. Drugs 2018, 16, 9. https://doi.org/10.3390/md16010009

25. Sun, Y.-T.; Lin, B.; Li, S.-G.; Liu, M.; Zhou, Y.-J.; Xu, Y.; Hua, H.-M.; Lin, H.-W. Tetrahedron 2017, 73, 2786. https://doi.org/10.1016/i.tet.2017.03.078 
26. Liu, H.-B.; Lauro, G.; O’Connor, R. D.; Lohith, K.; Kelly, M.; Colin, P.; Bifulco, G.; Bewley, C. A. J. Nat. Prod. 2017, 80, 2556.

https://doi.org/10.1021/acs.jnatprod.7b00452

27. Lorig-Roach, N.; Hamkins-Indik, F.; Johnson, T. A.; Tenney, K.; Valeriote, F. A.; Crews, P. Tetrahedron 2018, 74, 217. https://doi.org/10.1016/i.tet.2017.11.029

28. Kotoku, N.; Ishida, R.; Matsumoto, H.; Arai, M.; Toda, K.; Setiawan, A.; Muraoka, O.; Kobayashi, M. J. Org. Chem. 2017, 82, 1705.

https://doi.org/10.1021/acs.joc.6b02948

29. Campos, P.-E.; Wolfender, J.-L.; Queiroz, E. F.; Marcourt, L.; Al-Mourabit, A.; De Voogd, N.; Illien, B.; Gauvin-Bialecki, A. Tetrahedron Lett. 2017, 58, 3901.

https://doi.org/10.1016/i.tetlet.2017.08.072

30. Ragini, K.; Fromont, J.; Piggott, A. M.; Karuso, P. J. Nat. Prod. 2017, 80, 215. https://doi.org/10.1021/acs.jnatprod.6b01038

31. McCauley, E. P.; Lam, H.; Lorig-Roach, N.; Luu, J.; Lloyd, C.; Tenney, K.; Pietraszkiewicz, H.; Diaz, C.; Valeriote, F. A.; Auerbuch, V.; Crews, P. J. Nat. Prod. 2017, 80, 3255.

https://doi.org/10.1021/acs.jnatprod.7b00694

32. Chen, N.-F.; Su, Y.-D.; Hwang, T.-L.; Liao, Z.-J.; Tsui, K.-H.; Wen, Z.-H.; Wu, Y.-C.; Sung, P.-J. Molecules 2017, 22, 475.

https://doi.org/10.3390/molecules22030475

33. Cheng, W.; Li, X.; Yin, F.; van Ofwegen, L.; Lin, W. Chem. Biodiversity 2017, 14, e1700053. https://doi.org/10.1002/cbdv.201700053

34. Cheng, W.; Ji, M.; Li, X.; Ren, J.; Yin, F.; van Ofwegen, L.; Yu, S.; Chen, X.; Lin, W. Tetrahedron 2017, 73, 2518.

https://doi.org/10.1016/i.tet.2017.03.037

35. Shenkar, N.; Swalla, B. J. Plos ONE 2011, 6, e20657. https://doi.org/10.1371/journal.pone.0020657

36. Palanisamy, S. K.; Rajendran, N. M.; Marino, A. Nat. Prod. Bioprospect. 2017, 7, 1. https://doi.org/10.1007/s13659-016-0115-5

37. Wang, W.; Kim, H.; Patil, R. S.; Giri, A. G.; Won, D. H.; Hahn, D.; Sung, Y.; Lee, J.; Choi, H.; Nam, S.-J.; Kang, H. Bioorg. Med. Chem. Lett. 2017, 27, 574.

https://doi.org/10.1016/i.bmcl.2016.12.016

38. Hansen, K. Ø.; Isaksson, J.; Bayer, A.; Johansen, J. A.; Andersen, J. H.; Hansen, E. J. Nat. Prod. 2017, 80, 3276.

https://doi.org/10.1021/acs.jnatprod.7b00703

39. Maltseva, A. L.; Kotenko, O. N.; Kutyumov, V. A.; Matvienko, D. A.; Shavarda, A. L.; Winson, M. K.;

Ostrovsky, A. N. Nat. Prod. Res. 2017, 31, 1840.

https://doi.org/10.1080/14786419.2016.1261344

40. Wu, Z.; Li, Y.; Liu, D.; Ma, M.; Chen, J.; Lin, W. Chem. Biodiversity 2017, 14, e1700059. https://doi.org/10.1002/cbdv.201700059

41. Kong, F.-D.; Ma, Q.-Y.; Huang, S.-Z.; Wang, P.; Wang, J.-F.; Zhou, L.-M.; Yuan, J.-Z.; Dai, H.-F.; Zhao, Y.-X. J. Nat. Prod. 2017, 80, 1039.

https://doi.org/10.1021/acs.jnatprod.6b01061 
42. Kong, F.-D.; Zhang, R.-S.; Ma, Q.-Y.; Xie, Q.-Y.; Wang, P.; Chen, P.-W.; Zhou, L.-M.; Dai, H.-F.; Luo, D.-Q.; Zhao, Y.-X. Fitoterapia 2017, 122, 1.

https://doi.org/10.1016/i.fitote.2017.08.002

43. Liu, D.; Li, Y.; Li, X.; Cheng, Z.; Huang, J.; Proksch, P.; Lin, W. Tetrahedron Lett. 2017, 58, 1826.

https://doi.org/10.1016/i.tetlet.2017.03.079

44. Scopel, M.; Mothes, B.; Lerner, C. B.; Henriques, A. T.; Macedo, A. J.; Abraham, W.-R. Phytochem. Lett. 2017, 20, 73.

https://doi.org/10.1016/i.phytol.2017.04.010

45. Chen, M.; Shen, N.-X.; Chen, Z.-Q.; Zhang, F.-M.; Chen, Y. J. Nat. Prod. 2017, 80, 1081.

https://doi.org/10.1021/acs.jnatprod.6b01179

46. Luo, M.; Cui, Z.; Huang, H.; Song, X.; Sun, A.; Dang, Y.; Lu, L; Ju, J. J. Nat. Prod. 2017, 80, 1668. https://doi.org/10.1021/acs.jnatprod.7b00269

47. Nicacio, K. J.; lóca, L. P.; Fróes, A. M.; Leomil, L.; Appolinario, L. R.; Thompson, C. C.; Thompson, F. L.; Ferreira, A. G.; Williams, D. E.; Andersen, R. J.; Eustaquio, A. S.; Berlinck, R. G. S. J. Nat. Prod. 2017, 80, 235.

https://doi.org/10.1021/acs.jnatprod.6b00838

48. Asolkar, R. N.; Singh, A.; Jensen, P. R.; Aalbersberg, W.; Carté, B. K.; Feussner, K.-D.; Subramani, R.; DiPasquale, A.; Rheingold, A. L.; Fenical, W. Tetrahedron 2017, 73, 2234.

https://doi.org/10.1016/i.tet.2017.03.003

49. Wu, G.; Nielson, J. R.; Peterson, R. T.; Winter, J. M. Mar. Drugs 2017, 15, 195.

https://doi.org/10.3390/md15070195

50. Mo, S.; Krunic, A.; Chipala, G.; Orjala, J. J. Nat. Prod. 2009, 72, 894.

https://doi.org/10.1021/np800751j

51. Nunnery, J. K.; Mevers, E.; Gerwick, W. H. Curr. Opin. Biotechnol. 2010, 21, 787. https://doi.org/10.1021/np800751j

52. Gorham, P. R.; Carmichael, W. W. Pure Appl. Chem. 1980, 52, 165. https://doi.org/10.1351/pac198052010165

53. Moore, R. E. Bioscience 1977, 27, 797. https://doi.org/10.2307/1297756

54. Steffen, M. M.; Belisle, B. S.; Watson, S. B.; Boyer, G. L.; Wilhelm, S. W. J. Great Lakes Res. 2014, 40, 215. https://doi.org/10.1016/i.jglr.2013.12.012

55. Bertin, M. J.; Wahome, P. G.; Zimba, P. V.; He, H.; Moeller, P. D. R. Mar. Drugs 2017, 15, 10. https://doi.org/10.3390/md15010010

56. Belisle, R. S.; Via, C. W.; Schock, T. B.; Villareal, T. A.; Zimba, P. V.; Beauchesne, K. R.; Moeller, P. D. R.; Bertin, M. J. Tetrahedron Lett. 2017, 58, 4066.

https://doi.org/10.1016/i.tetlet.2017.09.027

57. Naman, C. B.; Almaliti, J.; Armstrong, L.; Caro-Díaz, E. J.; Pierce, M. L.; Glukhov, E.; Fenner, A.; Spadafora, C.; Debonsi, H. M.; Dorrestein, P. C.; Murray, T. F.; Gerwick, W. H. J. Nat. Prod. 2017, 80, 2328. https://doi.org/10.1021/acs.jnatprod.7b00367

58. Lopez, J. A. V.; Petitbois, J. G.; Vairappan, C. S.; Umezawa, T.; Matsuda, F.; Okino, T. Org. Lett. 2017, 19, 4231. https://doi.org/10.1021/acs.orglett.7b01869

59. Sueyoshi, K.; Yamano, A.; Ozaki, K.; Sumimoto, S.; Iwasaki, A.; Suenaga, K.; Teruya, T. Mar. Drugs 2017, 15, 367. 
https://doi.org/10.3390/md15120367

60. Petitbois, J. G.; Casalme, L. O.; Lopez, J. A. V.; Alarif, W. M.; Abdel-Lateff, A.; Al-Lihaibi, S. S.; Yoshimura, E.; Nogata, Y.; Umezawa, T.; Matsuda, F.; Okino, T. J. Nat. Prod. 2017, 80, 2708. https://doi.org/10.1021/acs.jnatprod.7b00449

61. Al-Awadhi, F. H.; Salvador, L. A.; Law, B. K.; Paul, V. J.; Luesch, H. Mar. Drugs 2017, 15, 290. https://doi.org/10.3390/md15090290

62. Sueyoshi, K.; Kudo, T.; Yamano, A.; Sumimoto, S.; Iwasaki, A.; Suenaga, K.; Teruya, T. Bull. Chem. Soc. Jpn. 2017, 90, 436.

https://doi.org/10.1246/bcsj.20160417

63. Nuzzo, G.; Gomes, B. A.; Amodeo, P.; Matthews-Cascon, H.; Cutignano, A.; Costa-Lotufo, L. V.; Monteiro, F. A. C.; Pessoa, O. D. L.; Fontana, A. J. Nat. Prod. 2017, 80, 3049.

https://doi.org/10.1021/acs.jnatprod.7b00510

64. Machida, K.; Matsumoto, T.; Fusetani, N.; Nakao, Y. Chem. Lett. 2017, 46, 1676. https://doi.org/10.1246/cl.170756

65. Murakami, A.; Miyashita, H.; Iseki, M.; Adachi, K.; Mimuro, M. Science 2004, 303, 1633. https://doi.org/10.1126/science.1095459

66. Dembitsky, V. M.; Gloriozova, T. A.; Poroikov, V. V. Int. J. Curr. Res. Biosci. Plant Biol. 2017, 4, 70. https://doi.org/10.20546/ijcrbp.2017.411.009

67. Xu, Y.-M.; Wijeratne, E. M. K.; Babyak, A. L.; Marks, H. R.; Brooks, A. D.; Tewary, P.; Xuan, L.-J.; Wang, W.Q.; Sayers, T. J.; Gunatilaka, A. A. L. J. Nat. Prod. 2017, 80, 1981.

https://doi.org/10.1021/acs.jnatprod.6b01129

68. Gonzalez, M. A. S.; Buenafe, M. E. G.; Ysrael, M. C. Acta Manilana 1993, 41, 17.

69. Macabeo, A. P. G.; Letada, A. G.; Budde, S.; Faderl, C.; Dahse, H.-M.; Franzblau, S. G.; Alejandro, G. J. D.; Pierens, G. K.; Garson, M. J. J. Nat. Prod. 2017, 80, 3319.

https://doi.org/10.1021/acs.jnatprod.7b00679

70. Nyandoro, S. S.; Munissi, J. J. E.; Gruhonjic, A.; Duffy, S.; Pan, F.; Puttreddy, R.; Holleran, J. P.; Fitzpatrick, P. A.; Pelletier, J.; Avery, V. M.; Rissanen, K.; Erdélyi, M. J. Nat. Prod. 2017, 80, 114.

https://doi.org/10.1021/acs.jnatprod.6b00759

71. Verzer, R.; Petri, G. J. Ethnopharmacol. 1987, 19, 67.

https://doi.org/10.1016/0378-8741(87)90137-1

72. Huo, H.-X.; Gu, Y.-F.; Sun, H.; Zhang, Y.-F.; Liu, W.-J.; Zhu, Z.-X.; Shi, S.-P.; Song, Y.-L.; Jin, H.-W.; Zhao, Y.F.; Tu, P.-F.; Li, J. Fitoterapia 2017, 118, 49.

https://doi.org/10.1016/j.fitote.2017.02.009

73. Hassan, A. R.; El-Kousy, S. M.; El-Toumy, S. A.; Frydenvang, K.; Tung, T. T.; Olsen, J.; Nielsen, J.;

Christensen, S. B. J. Nat. Prod. 2017, 80, 2830.

https://doi.org/10.1021/acs.jnatprod.7b00106

74. Chen, X.; Zuo, A.; Deng, Z.; Huang, X.; Zhang, X.; Geng, C.; Li, T.; Chen, J. Fitoterapia 2017, $122,144$. https://doi.org/10.1016/i.fitote.2017.09.009

75. Zhao, M.; Da-Wa, Z.-M.; Gu, Y.-C.; Guo, D.-L.; Ye, Y.; Ding, L.-S.; Zhou, Y. Phytochem. Lett. 2017, $20,168$. https://doi.org/10.1016/i.phytol.2017.04.037

76. Mathela, C. S.; Chanotiya, C. S.; Sammal, S. S.; Pant, A. K.; Pandey, S. Chem. Biodivers. 2005, 2, 1174. https://doi.org/10.1002/cbdv.200590087

77. Wang, R.-J.; Chen, H.-M.; Yang, F.; Deng, Y.; AO, H.; Xie, X.-F.; Li, H.-X.; Zhang, H.; Cao, Z.-X.; Zhu, L.-X.; Chen, Y.; Peng, C.; Tan, Y.-Z. Phytochemistry 2017, 141, 156. 
https://doi.org/10.1016/i.phytochem.2017.05.010

78. Li, X.-H.; Li, X.-H.; Yao, Q.; Lu, L.-H.; Li, Y.-B.; Wu, D.-S.; Fu, D.-H.; Mei, S.-X.; Cui, T.; Wang, J.-K.; Zhu, Z.-Y. Tetrahedron Lett. 2017, 58, 3112.

https://doi.org/10.1016/j.tetlet.2017.06.078

79. Li, Y.; Zhu, Y.-X.; Zhang, Z.-X.; Liu, Y.-L.; Liu, Y.; Qu, J.; Ma, S.-G.; Wang, X.-J.; Yu, S.-S. Tetrahedron 2018, 74, 693.

https://doi.org/10.1016/j.tet.2017.12.017

80. Al-Khdhairawi, A. A. Q.; Krishnan, P.; Mai, C.-W.; Chung, F. F.-L.; Leong, C.-O.; Yong, K.-T.; Chong, K.-W.; Low, Y.-Y.; Kam, T.-S.; Lim, K.-H. J. Nat. Prod. 2017, 80, 2734.

https://doi.org/10.1021/acs.jnatprod.7b00500

81. Zeng, J.; Zhang, D.-B.; Zhou, P.-P.; Zhang, Q.-L.; Zhao, L.; Chen, J.-J.; Gao, K. Org. Lett. 2017, $19,3998$. https://doi.org/10.1021/acs.orglett.7b01723

82. Dean, R.; Van Kan, J. A. L.; Pretorius, Z. A. et al. Mol. Plant Pathol. 2012, 13, 414. https://doi.org/10.1111/j.1364-3703.2011.00783.x

83. Masi, M.; Cimmino, A.; Boari, A.; Zonno, M. C.; Górecki, M.; Pescitelli, G.; Tuzi, A.; Vurro, M.; Evidente, A. Tetrahedron 2017, 73, 6644.

https://doi.org/10.1016/j.tet.2017.10.018

84. Phainuphong, P.; Rukachaisirikul, V.; Phongpaichit, S.; Preedanon, S.; Sakayaroj, J. Tetrahedron 2017, 73, 5920.

https://doi.org/10.1016/j.tet.2017.08.039

85. Ali, T.; Inagaki, M.; Chai, H.; Wieboldt, T.; Rapplye, C.; Rakotondraibe, L. H. J. Nat. Prod. 2017, 80, 1397. https://doi.org/10.1021/acs.jnatprod.6b01069

86. Hi, K.-Y.; Zhang, C.; Duan, Y.-R.; Huang, G.-L.; Yang, C.-Y.; Lu, X.-R.; Zheng, C.-J.; Chen, G.-Y. J. Antibiot. 2017, 70, 823.

https://doi.org/10.1038/ja.2017.52

87. Masi, M.; Meyer, S.; Clement, S.; Pescitelli, G.; Cimmino, A.; Cristofaro, M.; Evidente, A. J. Nat. Prod. 2017, 80, 2771.

https://doi.org/10.1021/acs.jnatprod.7b00583

88. Song, R.-Y.; Liu, Y.; Liu, R.-H.; Wang, X.-B.; Li, T.-X.; Kong, L.-Y.; Yang, M.-H. Phytochem. Lett. 2017, 22, 189.

https://doi.org/10.1016/j.phytol.2017.10.006

89. Yanaka, S.; Honmura, Y.; Uesugi, S.; Fukushi, E.; Tanaka, K.; Maeda, H.; Kimura, K.; Nehira, T.; Hashimoto, M. J. Org. Chem. 2017, 82, 5574.

https://doi.org/10.1021/acs.joc.7b00393

90. Verastegui-Omaña, B.; Rebollar-Ramos, D.; Pérez-Vásquez, A.; Martínez, A. L.; Madariaga-Mazón, A.;

Flores-Bocanegra, L.; Mata, R. J. Nat. Prod. 2017, 80, 190.

https://doi.org/10.1021/acs.jnatprod.6b00977

91. Zhang, D.; Zhao, L.; Wang, L.; Fang, X.; Zhao, J.; Wang, X.; Li, L.; Liu, H.; Wei, Y.; You, X.; Cen, S.; Yu, L. J. Nat. Prod. 2017, 80, 371.

https://doi.org/10.1021/acs.jnatprod.6b00829

92. Zhu, M.; Zhang, X.; Feng, H.; Dai, J.; Li, J.; Che, Q.; Gu, Q.; Zhu, T.; Li, D. J. Nat. Prod. 2017, 80, 71. https://doi.org/10.1021/acs.jnatprod.6b00483

93. Schloß, S.; Hackl, T.; Herz, C.; Lamy, E.; Koch, M.; Rohn, S.; Maul, R. J. Nat. Prod. 2017, 80, 1930. https://doi.org/10.1021/acs.jnatprod.6b00662 
94. Bashyal, B. P.; Wijeratne, E. M. K.; Tillotson, J.; Arnold, A. E.; Chapman, E.; Gunatilaka, A. A. L. J. Nat. Prod. 2017, 80, 427.

https://doi.org/10.1021/acs.jnatprod.6b00960

95. Kang, H.-S.; Ji, S.-A.; Park, S.-H.; Kim, J.-P. Phytochemistry 2017, 143, 111.

https://doi.org/10.1016/i.phytochem.2017.08.003

96. Zhang, P.-L.; Han, Y.; Zhang, L.-T.; Wang, X.-L.; Shen, T.; Ren, D.; Lou, H.; Wang, X.-N. J. Nat. Prod. 2017, 80, 1791.

https://doi.org/10.1021/acs.jnatprod.6b01196

97. Shiono, Y.; Muslihah, N. I.; Suzuki, T.; Ariefta, N. R.; Anwar, C.; Nurjanto, H. H.; Aboshi, T.; Murayama, T.; Tawaraya, K.; Koseki, T.; Yoshida, J.; Usukhbayar, N.; Uesugi, S.; Kimura, K. J. Antibiot. 2017, 70, 1133. https://doi.org/10.1038/ja.2017.125

98. Cruz, J. C. S.; Maffioli, S. I.; Bernasconi, A.; Brunati, C.; Gaspari, E.; Sosio, M.; Wellington, E.; Donadio, S. J. Antibiot. 2017, 70, 73.

https://doi.org/10.1038/ja.2016.62

99. Igarashi, Y.; Matsuoka, N.; In, Y.; Kataura, T.; Tashiro, E.; Saiki, I.; Sudoh, Y.; Duangmal, K.;

Thamchaipenet, A. Org. Lett. 2017, 19, 1406.

https://doi.org/10.1021/acs.orglett.7b00318

100. Shin, Y.-H.; Bae, S.; Sim, J.; Hur, J.; Jo, S.-I.; Shin, J.; Suh, Y.-G.; Oh, K.-B.; Oh, D.-C. J. Nat. Prod. 2017, 80, 2962.

https://doi.org/10.1021/acs.jnatprod.7b00506

101. Son, S.; Hong, Y.-S.; Jang, M.; Heo, K. T.; Lee, B.; Jang, J.-P.; Kim, J.-W.; Ryoo, I.-J.; Kim, W.-G.; Ko, S.-K.; Kim, B. Y.; Jang, J.-H.; Ahn, J. S. J. Nat. Prod. 2017, 80, 3025.

https://doi.org/10.1021/acs.jnatprod.7b00660

102. Dardić, D.; Lauro, G.; Bilfulco, G.; Laboudie, P.; Sakhaii, P.; Bauer, A.; Vilcinskas, A.; Hammann, P. E.; Plaza, A. J. Org. Chem. 2017, 82, 6032.

https://doi.org/10.1021/acs.joc.7b00228

103. Hoffmann, T.; Müller, S.; Nadmid, S.; Garcia, R.; Müller, R. J. Am. Chem. Soc. 2013, 135, 16904. https://doi.org/10.1021/ja4054509

104. Kikuchi, H.; Ito, I.; Takahashi, K.; Ishigaki, H.; lizumi, K.; Kubohara, Y.; Oshima, Y. J. Nat. Prod. 2017, 80, 2716.

\section{https://doi.org/10.1021/acs.jnatprod.7b00456}

105. Khalil, M. A. K.; Rasmussen, R. A.; French, J. R. J.; Holt, J. A. J. Geophys. Res. Atmos. 1990, $95,3619$. https://doi.org/10.1029/JD095iD04p03619

106. Berberich, G. M.; Sattler, T.; Klimetzek, D.; Benk, S. A.; Berberich, M. B.; Polag, D.; Schöler, H. F.; Atlas, E. J. Atmos. Chem. 2017, 74, 261.

https://doi.org/10.1007/s10874-016-9358-0

107. Fayolle, E. C.; Öberg, K. I.; Jørgensen, J. K.; Altwegg, K.; Calcutt, H.; Müller, H. S. P.; Rubin, M.; van der Wiel, M. H. D.; Bjerkeli, P.; Bourke, T. L.; Coutens, A.; van Dishoeck, E. F.; Drozdovskaya, M. N.; Garrod, R. T.; Ligterink, N. F. W.; Persson, M. V.; Wampfler, S. F.; and the ROSINA team Nature Astronomy 2017, 1, 703.

108. Lim, Y.-K.; Phang, S.-M.; Rahman, N. A.; Sturges, W. T.; Malin, G. Int. J. Environ. Sci. Technol. 2017, 14, 1355.

https://doi.org/10.1007/s13762-016-1219-5

109. Ziska, F.; Quack, B.; Tegtmeier, S.; Stemmler, I.; Krüger, K. J. Atmos. Chem. 2017, 74, 245. 
https://doi.org/10.1007/s10874-016-9355-3

110. Xue, R.; Shi, H.; Ma, Y.; Yang, J.; Hua, B.; Inniss, E. C.; Adams, C. D.; Eichholz, T. Chemosphere 2017, 189, 349.

https://doi.org/10.1016/j.chemosphere.2017.09.059

111. Barbier, M. Marine Natural Products. In Marine Natural Products; Scheuer, P. J., Ed.; Academic: New York, 1981; Vol. IV, p 147.

https://doi.org/10.1016/B978-0-12-624004-7.50011-1

112. Porter, N.; Fox, F. M. Pestic. Sci. 1993, 39, 161.

https://doi.org/10.1002/ps.2780390210 